\title{
Dissolved carbon biogeochemistry and export in mangrove-dominated rivers of the Florida Everglades
}

\author{
David T. Ho ${ }^{1}$, Sara Ferrón ${ }^{1}$, Victor C. Engel ${ }^{2, a}$, William T. Anderson ${ }^{3,4}$, Peter K. Swart ${ }^{5}$, René M. Price ${ }^{3,4}$, and \\ Leticia Barbero ${ }^{6}$ \\ ${ }^{1}$ Department of Oceanography, University of Hawaii, Honolulu, Hawaii 96822, USA \\ ${ }^{2}$ South Florida Natural Resources Center, Everglades National Park, Homestead, Florida 33030, USA \\ ${ }^{3}$ Southeast Environmental Research Center, Florida International University, Miami, Florida 33199, USA \\ ${ }^{4}$ Department of Earth and Environment, Florida International University, Miami, Florida 33199, USA \\ ${ }^{5}$ Department of Marine Geosciences, Rosenstiel School of Marine and Atmospheric Science, University of Miami, Miami, \\ Florida 33149, USA \\ ${ }^{6}$ NOAA Atlantic Oceanographic and Meteorological Laboratory, Miami, Florida 33149, USA \\ anow at: U.S. Forest Service, Fort Collins, Colorado 80526, USA
}

Correspondence to: David T. Ho (david.ho@hawaii.edu)

Received: 10 January 2017 - Discussion started: 11 January 2017

Revised: 8 April 2017 - Accepted: 19 April 2017 - Published: 17 May 2017

\begin{abstract}
The Shark and Harney rivers, located on the southwest coast of Florida, USA, originate in the freshwater, karstic marshes of the Everglades and flow through the largest contiguous mangrove forest in North America. In November 2010 and 2011, dissolved carbon source-sink dynamics was examined in these rivers during $\mathrm{SF}_{6}$ tracer release experiments. Approximately $80 \%$ of the total dissolved carbon flux out of the Shark and Harney rivers during these experiments was in the form of inorganic carbon, either via air-water $\mathrm{CO}_{2}$ exchange or longitudinal flux of dissolved inorganic carbon (DIC) to the coastal ocean. Between 42 and $48 \%$ of the total mangrove-derived DIC flux into the rivers was emitted to the atmosphere, with the remaining being discharged to the coastal ocean. Dissolved organic carbon (DOC) represented ca. $10 \%$ of the total mangrove-derived dissolved carbon flux from the forests to the rivers. The sum of mangrove-derived DIC and DOC export from the forest to these rivers was estimated to be at least 18.9 to $24.5 \mathrm{mmol} \mathrm{m}^{-2} \mathrm{~d}^{-1}$, a rate lower than other independent estimates from Shark River and from other mangrove forests. Results from these experiments also suggest that in Shark and Harney rivers, mangrove contribution to the estuarine flux of dissolved carbon to the ocean is less than $10 \%$.
\end{abstract}

\section{Introduction}

In many tropical and subtropical regions, mangrove forests are a typical feature surrounding estuaries (Twilley et al., 1992; Bouillon et al., 2008a). Mangroves are thought to play an important role in tropical and subtropical coastal biogeochemical cycling and the global coastal carbon budget, due to their high productivity and rapid cycling of organic and inorganic carbon (Twilley et al., 1992; Jennerjahn and Ittekkot, 2002; Dittmar et al., 2006). However, there remain uncertainties regarding the fate of mangrove-fixed carbon and the amount of carbon exported to the coastal waters from these ecosystems (Bouillon et al., 2008a, b; Kristensen et al., 2008).

Bouillon et al. (2008a) showed that over $50 \%$ of the carbon fixed by mangroves through photosynthesis could not be accounted for by growth in biomass, accumulation in soils, and export of organic carbon, and suggested that a large fraction of this missing organic carbon may be mineralized to dissolved inorganic carbon (DIC) and either lost to the atmosphere or exported to the surrounding waters. In fact, several studies have shown that the lateral advective transport of interstitial waters through tidal pumping represents a major carbon export pathway from mangroves into adjacent waters, both for DIC (Koné and Borges, 2008; Miyajima et al., 2009; 
Maher et al., 2013) and dissolved organic carbon (DOC) (Dittmar and Lara, 2001; Bouillon et al., 2007c). However, to date, lateral mangrove-derived aquatic carbon fluxes (as a proportion of overall forest carbon mass balance) have only been estimated for short time periods and over limited spatial (e.g., plot) scales (e.g., Troxler et al., 2015). These studies also typically do not determine the fate of mangrove-derived carbon once it is exported from the forest through tidal pumping and drainage. Additional measurements of the magnitude and fate of mangrove carbon export at the basin scale are needed to help quantify connections between inter-tidal, estuarine, and coastal ocean carbon cycles.

Rates of lateral dissolved carbon export from tidal mangrove forest are heterogeneous over space and time due to variability in inundation patterns, forest structure, topography, and soil hydraulic properties. Direct, plot-scale measurements of dissolved carbon export therefore may not represent rates quantified at the basin scale. However, mangrove-derived dissolved carbon fluxes may be estimated in some systems using information on the spatial distribution of carbon-related measurements in adjacent waters. For example, the carbon balance of tidal riverine systems adjacent to mangrove forests should integrate the spatial and temporal variability of these lateral fluxes.

The objective of this study is to quantify dissolved carbon source-sink dynamics in a subtropical estuary dominated by two tidal rivers, the Shark and Harney rivers in Everglades National Park, Florida, USA. These rivers are centrally located within the largest contiguous mangrove forest in North America and they discharge to the Gulf of Mexico. The total dissolved carbon inventories and fluxes in these rivers are determined using a series of discrete and continuous measurements of carbon-related parameters along a salinity gradient, and the mangrove contribution separated using measurements of stable isotopic composition of dissolved organic and inorganic carbon. The results are then scaled by the area of mangrove forest that surrounds these rivers to express dissolved carbon fluxes on an aerial basis for comparison to independent measurements of dissolved carbon fluxes from this forest.

\section{Methods}

\subsection{Study site}

The tidal-dominated Shark and Harney rivers (river and estuary are used interchangeably in this contribution) are surrounded by mangrove forests and located on the southwest coast of Florida (Fig. 1), within Everglades National Park. The subtropical climate in southern Florida is characterized by a May to October wet season, when approximately $60 \%$ of the annual precipitation occurs (Southeast Regional Climate Center, http://www.sercc.com). The Shark and Harney rivers together discharge approximately $50 \%$ of the flow from the Shark River Slough (SRS), the primary drainage feature of Everglades National Park, to the Gulf of Mexico (GOM) (Levesque, 2004). Seasonal variation of the water discharge from SRS mostly follows the precipitation patterns (Saha et al., 2012), and influences the transport of nutrients to the mangrove ecotone (Rivera-Monroy et al., 2011). The Shark and Harney rivers are each approximately $15 \mathrm{~km}$ long, and connect in Tarpon Bay (Fig. 1). The mean depths of Tarpon Bay, Shark River, and Harney River at mid-tide are $1.4 \pm 0.3,2.8 \pm 0.4$, and $2.6 \pm 0.4 \mathrm{~m}$ (Ho et al., 2014), respectively, and the surface areas are $1.48 \times 10^{6}, 2.54 \times 10^{6}$, and $2.75 \times 10^{6} \mathrm{~m}^{2}$, respectively. The inter-tidal zones bordering the Shark and Harney rivers are dominated by Rhizophora mangle (red mangrove), Avicennia germinans (black mangrove), Laguncularia racemose (white mangrove), and Conocarpus erectus (buttonwood). Semi-diurnal tides in this region inundate the forest as often as twice a day. River discharge to the GOM is primarily influenced by tides, wind, and freshwater inflow from SRS (Levesque, 2004).

Discharges are determined by the US Geological Survey at stations near the midpoints of Shark River (USGS 252230081021300 Shark River) and Harney River (USGS 252551081050900 Harney River) (Fig. 1). Discharges are generally lower during March-May than the rest of the year. Hourly mean residual discharge values (i.e., filtered for tides) from March to May of the 5-year period from 2007 to 2011 ranged from -21.9 to $24.1 \mathrm{~m}^{3} \mathrm{~s}^{-1}$, with a mean of $0 \mathrm{~m}^{3} \mathrm{~s}^{-1}$ for Shark River, and ranged from -28.9 to $38.5 \mathrm{~m}^{3} \mathrm{~s}^{-1}$, with a mean of $4.4 \mathrm{~m}^{3} \mathrm{~s}^{-1}$ for Harney River. Positive values indicate flow towards the GOM. For the rest of the year (i.e., June to February), these values ranged from -46.2 to $89.2 \mathrm{~m}^{3} \mathrm{~s}^{-1}$, with a mean of $8.8 \mathrm{~m}^{3} \mathrm{~s}^{-1}$ for Shark River, and -41.6 to $75.0 \mathrm{~m}^{3} \mathrm{~s}^{-1}$, with a mean of $11.3 \mathrm{~m}^{3} \mathrm{~s}^{-1}$ for Harney River.

\subsection{Shark River Tracer Release Experiments}

Two field studies were conducted as part of the Shark River Tracer Release Experiment (SharkTREx 1: 20 to 25 November 2010; SharkTREx 2: 10 to 15 November 2011; Ho et al., 2014). The mean residual discharges for Shark River were 6.9 (hourly range: -2 to 19.9 ) and 4.9 (hourly range: -18.9 to 34.8$) \mathrm{m}^{3} \mathrm{~s}^{-1}$, during SharkTREx 1 and 2, respectively, and those for Harney River were 6.0 (hourly range: -1.6 to 22.8 ) and 1.9 (hourly range: -17.3 to 30.6$) \mathrm{m}^{3} \mathrm{~s}^{-1}$, during SharkTREx 1 and 2, respectively (U.S. Geological Survey, 2016).

During both campaigns, an inert tracer (sulfur hexafluoride; $\mathrm{SF}_{6}$ ) was injected in the river near the point where the rivers diverge just downstream of Tarpon Bay (25.4092, -81.0083 ) to determine the rates of longitudinal dispersion, and the water residence time. Each day, longitudinal surveys were made along the Shark and Harney rivers from Tarpon Bay to the GOM, and included continuous underway measurements of temperature, salinity, $\mathrm{SF}_{6}$, dissolved $\mathrm{O}_{2}$ (DO; $\left.\mu \mathrm{mol} \mathrm{kg}{ }^{-1}\right)$, and partial pressure of $\mathrm{CO}_{2}\left(p \mathrm{CO}_{2} ; \mu \mathrm{atm}\right)$, and discrete measurements of total alkalinity (TAlk; $\mu \mathrm{mol} \mathrm{kg}{ }^{-1}$ ), 


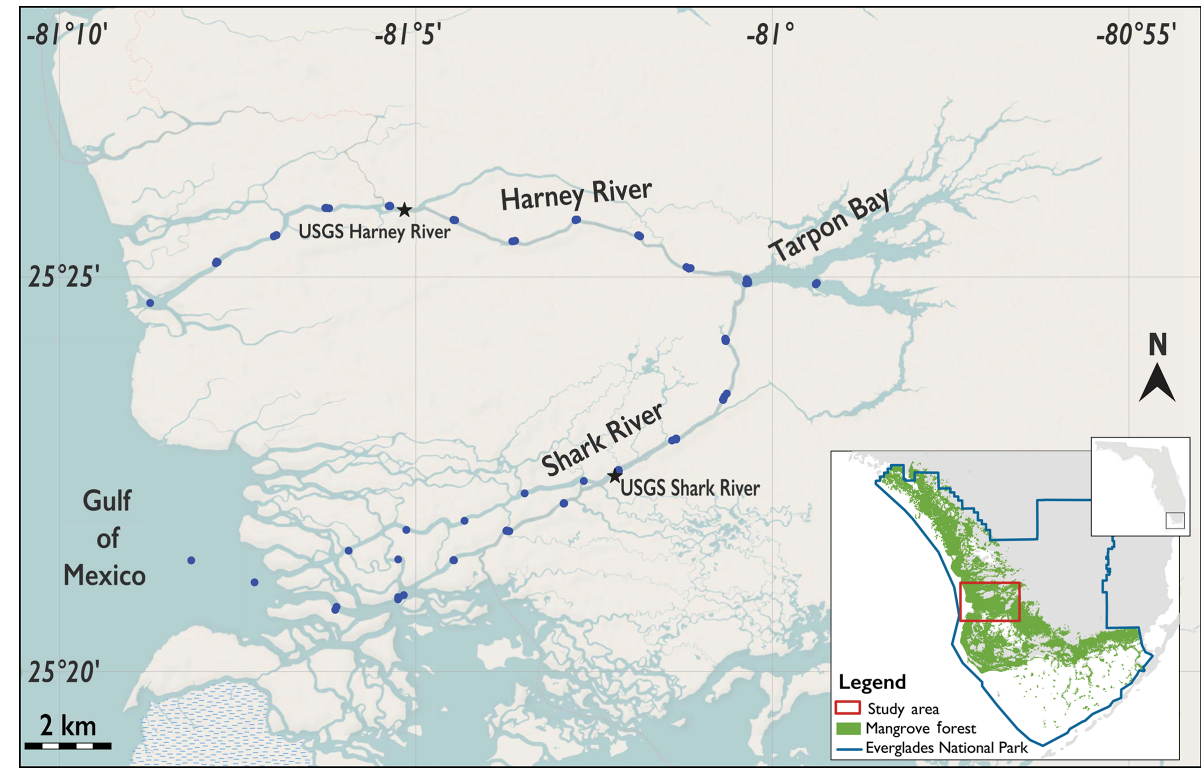

Figure 1. Map of the study area near the southern tip of Florida, USA, showing locations of Shark River, Harney River, and Tarpon Bay. The blue circles indicate the locations where discrete samples were taken, and the black stars denote the USGS gaging stations on both rivers. The green areas in the inset are part of the largest contiguous mangrove forest in North America. Indicated in the inset are the boundaries of Everglades National Park.

DIC $\left(\mu \mathrm{mol} \mathrm{kg}{ }^{-1}\right)$, DOC $\left(\mu \mathrm{mol} \mathrm{kg}{ }^{-1}\right)$, and stable carbon isotopic composition of DIC and DOC $\left(\delta^{13} \mathrm{C}_{\text {DIC }}\right.$ and $\delta^{13} \mathrm{C}_{\mathrm{DOC}}$, respectively; \%o).

\subsection{Discrete measurements}

During SharkTREx 1, three to five surface water samples were collected daily in the Shark River with a $5 \mathrm{~L}$ Niskin bottle at $\sim 0.5 \mathrm{~m}$ below the surface for the analysis of TAlk, DOC, $\delta^{13} \mathrm{C}_{\text {DIC }}$, and $\delta^{13} \mathrm{C}_{\text {DOC }}$. At each sampling site, vertical profiles of temperature, salinity, and DO were recorded using a conductivity, temperature, and depth sonde (Sea-Bird SBE 19plus V2) equipped with a Clark type polarographic $\mathrm{O}_{2}$ sensor (SBE 43). These profiles showed that the water column was vertically well mixed. No discrete samples were collected in the Harney River during SharkTREx 1. During SharkTREx 2, discrete samples for DIC, TAlk, DOC, $\delta^{13} \mathrm{C}_{\text {DIC }}$, and $\delta^{13} \mathrm{C}_{\mathrm{DOC}}$ were collected daily at 20 stations distributed within the Shark and Harney rivers (Fig. 1).

\subsubsection{Total alkalinity and dissolved inorganic carbon}

During SharkTREx 1, samples for TAlk were collected in $250 \mathrm{~mL}$ HDPE bottles after passing through a $0.45 \mu \mathrm{m}$ filter. They were stored on ice for transport to the laboratory at Florida International University (FIU), where TAlk was determined at room temperature using an automated titrator (Brinkman Titrino 751) with $0.1 \mathrm{~N} \mathrm{HCl}$ to a $\mathrm{pH}$ of 2 . TAlk was calculated from the volume of acid added at the inflection point closest to a $\mathrm{pH}$ of 4 , and reported as $\mu \mathrm{mol} \mathrm{L}^{-1}$
$\mathrm{HCO}_{3}^{-}$since the original $\mathrm{pH}$ of the water samples was near neutral. The precision of the measurements was $\pm 2 \%$ from replicate analysis $(n=5)$ with an accuracy of $\pm 2 \%$ as determined by analysis of certified reference material (Dickson, 2010). DIC and $\mathrm{pH}$ were computed from TAlk and $p \mathrm{CO}_{2}$ using the dissociation constants of Cai and Wang (1998) for estuarine waters.

During SharkTREx 2, samples for TAlk and DIC were collected in $550 \mathrm{~mL}$ borosilicate glass bottles, poisoned with $\mathrm{HgCl}_{2}$, and sealed with hydrocarbon grease (Apiezon $\mathrm{M}$ ). The samples were stored at room temperature in the dark for travel to the laboratory at NOAA/AOML. Samples for TAlk were measured in an open thermostated cell $\left(25^{\circ} \mathrm{C}\right)$ with an automated titrator (Metrohm 765 Dosimat) connected to a pH glass-reference electrode system (Orion), using $0.2 \mathrm{M}$ $\mathrm{HCl}$ as a titrant, and determined from the equivalence point of the titration curve using a nonlinear least-squares fit. For DIC analysis, water samples were first acidified to convert all the carbonate species to $\mathrm{CO}_{2}$ in a DIC analyzer (Apollo SciTech), and then measured with a non-dispersive infrared absorption (NDIR) detector (LI-COR LI-7000). Calibrations for DIC and TAlk were performed using certified reference material (Dickson, 2010). The analytical uncertainty of the DIC and TAlk measurements based on replicate samples are 0.1 and $0.2 \%$, respectively.

The measured TAlk and $p \mathrm{CO}_{2}$ from SharkTREx 2 were used to calculate DIC using CO2SYS (Pierrot et al., 2006) and the dissociation constants of Cai and Wang (1998), and the results were $1.3 \pm 1.1 \%$ (mean $\pm \mathrm{SD} ; n=77$; range: -2.4 to $+4.4 \%$ ) higher than the measured DIC, possibly in- 
dicating a slight contribution (ca. 1\%) to TAlk from organic or particulate material, as the samples were not filtered.

\subsubsection{Dissolved organic carbon}

The samples analyzed for DOC were filtered with precombusted $0.7 \mu \mathrm{m} \mathrm{GF} / \mathrm{F}$ filters and collected in precleaned, acid-washed, brown high-density polyethylene bottles (HDPE; Nalgene). Containers were rinsed 3 times before sample collection, transported on ice to the FIU SERC Nutrient Analysis Lab, and stored in a refrigerator until analyses within 3 weeks of collection. DOC was measured using the high-temperature catalytic combustion method on a total organic carbon analyzer (Shimadzu TOC-V), and standardized using 10 and $50 \mathrm{ppm}$ of potassium hydrogen phthalate (KHP), with reagent water as a blank. The analytical precision based on replicates of KHP is ca. $\pm 25 \mu \mathrm{mol} \mathrm{kg}{ }^{-1}$.

\subsubsection{Stable carbon isotopic composition}

Samples for $\delta^{13} \mathrm{C}_{\mathrm{DIC}}$ were collected in $40 \mathrm{~mL}$ glass bottles after passing the sample through a GF/F filter, and then poisoning with $\mathrm{HgCl}_{2}$. In the laboratory at the Rosenstiel School of Marine and Atmospheric Sciences, vials with $0.5 \mathrm{~mL}$ $103 \% \mathrm{H}_{3} \mathrm{PO}_{4}$ were flushed for $60 \mathrm{~s}$ with $\mathrm{He}$. Approximately $2 \mathrm{~mL}$ of sample were then injected into the vial, and after sonification the accumulated $\mathrm{CO}_{2}$ was analyzed by a gas chromatograph (GC) coupled to an isotope ratio mass spectrometer (GC-IRMS; Thermo Delta V). The $\delta^{13} \mathrm{C}$ was calibrated using two standards of $\mathrm{NHCO}_{3}$ with differing $\delta^{13} \mathrm{C}$ values dissolved in $\mathrm{H}_{2} \mathrm{O}$, whose isotopic compositions had been previously calibrated relative to NBS-19 using conventional dual inlet mass spectrometry (Finnigan-MAT 251). The $\delta^{13} \mathrm{C}$ values are reported relative to the Vienna Pee Dee Belemnite (VPDB) standard, and has a reproducibility of $\pm 0.2 \%$ as determined by repeated analysis of internal DIC standards.

Samples for $\delta^{13} \mathrm{C}_{\mathrm{DOC}}$ were collected in $60 \mathrm{~mL}$ brown HDPE bottles and stored on ice until returned to the lab at FIU. $\delta^{13} \mathrm{C}_{\mathrm{DOC}}$ samples were filtered with $\mathrm{GF} / \mathrm{F}(0.7 \mu \mathrm{m})$ filter, and then stored in pre-cleaned $40 \mathrm{~mL}$ bottles until analyses. Measurements for $\delta^{13} \mathrm{C}_{\mathrm{DOC}}$ were made using a total organic carbon (TOC) analyzer (Aurora 1030W, OI Analytical) coupled to a cavity ring-down spectroscopy system (CRDS; G1111-i, Picarro) following the approach of Ya et al. (2015). DIC was removed by adding $\mathrm{H}_{3} \mathrm{PO}_{4}$ and sparging with $\mathrm{N}_{2} .1 .5 \mathrm{~mL}$ of sample was chemically oxidized to $\mathrm{CO}_{2}$ at a temperature of $98^{\circ} \mathrm{C}$ in the presence of sodium persulfate $\left(\mathrm{Na}_{2} \mathrm{~S}_{2} \mathrm{O}_{8}\right)$. The $\mathrm{CO}_{2}$ generated was detected by NDIR for determination of DOC. The $\mathrm{CO}_{2}$ was collected in a gas-tight bag and then pulsed into the CRDS for the $\delta^{13} \mathrm{C}$ measurement. In order to measure the different isotopic ranges within the collected samples, an isotopic calibration was based on two external standards of potassium hydrogen phthalate (KHP $-29.8 \%$, OI-Analytical) and glu- tamine $(-11.45 \%$, Fisher) with a concentration range of $0-$ $2080 \mu \mathrm{mol} \mathrm{kg}{ }^{-1}$. These standards were prepared in synthetic seawater to match the salinity of the sample matrix. The isotope values of these two standards were determined by using an elemental analyzer isotope ratio mass spectrometer (EAIRMS). Analytical precision based on replicated standards ranged from \pm 0.15 to $\pm 1.52 \%$ o for this study.

\subsection{Underway measurements}

Surface water was continuously pumped from an intake located near the bow of the boat at a water depth of approximately $1 \mathrm{~m}$ during tracer recovery operations. Water temperature and salinity were continuously recorded using a thermosalinograph (SBE 45 MicroTSG). During SharkTREx 1, DO was measured underway with a membrane covered galvanic sensor (WTW Cellox 325) calibrated with saturated air. During SharkTREx 2, DO was measured using an oxygen optode (Aanderaa 3835) calibrated against Winkler titration.

Underway measurements of atmospheric and waterside $p \mathrm{CO}_{2}$ were made. Waterside $p \mathrm{CO}_{2}$ were obtained with a showerhead type equilibrator coupled to a NDIR analyzer (LI-COR 840A). Measurements of underway $\mathrm{SF}_{6}$ were made with an automated $\mathrm{SF}_{6}$ analysis system (Ho et al., 2002), which is comprised of gas extraction (membrane contactor), separation (molecular sieve 5A), and detection units (gas chromatograph equipped with an electron capture detector). Both the underway $p \mathrm{CO}_{2}$ and $\mathrm{SF}_{6}$ measurements are described in greater detail in Ho et al. (2014)

\subsection{Inventories of DIC, DOC, and DO}

The inventories of DIC, DOC, and DO were calculated in the same way that $\mathrm{SF}_{6}$ inventories were determined in $\mathrm{Ho}$ et al. (2014). The river was divided into $100 \mathrm{~m}$ longitudinal sections, and the measured concentrations, corrected for tidal movement to slack before ebb for each day, were assigned to each section $i$ and then summed over the entire length of the river. For example, to calculate the inventory of DIC, denoted $\sum[\mathrm{DIC}]_{\text {observed }}(\mathrm{mol})$ :

$\sum[\mathrm{DIC}]_{\mathrm{observed}}=\sum_{i=1}^{n}[\mathrm{DIC}]_{i} \times V_{i}$,

where $[\mathrm{DIC}]_{i}$ is the mean concentration $\left(\mathrm{mol} \mathrm{L}^{-1}\right)$ in section $i, V_{i}$ is the volume of the river (L) in section $i$ at midtide, and $n$ is the number of sections in each river $(n=273$ for Shark River and Tarpon Bay; $n=152$ for Harney River). DOC and DO inventories were also calculated using Eq. (1), by substituting $[\mathrm{DOC}]_{i}$ or $[\mathrm{DO}]_{i}$ for $[\mathrm{DIC}]_{i}$ accordingly. The inventories of DIC and DOC were separated into contributions from estuarine and non-estuarine sources, first by determining inventories for DIC assuming conservative mixing between the freshwater and marine end-members and then subtracting these inventories from the total observed inventories while correcting for air-water gas exchange. The es- 
tuarine DIC inventory, $\sum[\mathrm{DIC}]_{\text {estuary }}$, representing the DIC from all estuarine sources, was calculated as follows:

$$
\begin{aligned}
\sum[\mathrm{DIC}]_{\mathrm{estuary}} & =\sum[\mathrm{DIC}]_{\mathrm{observed}}-\sum[\mathrm{DIC}]_{\mathrm{conserv}} \\
& +\sum[\mathrm{DIC}]_{\mathrm{gasex}},
\end{aligned}
$$

where $\sum[D I C]_{\text {conserv }}$ is the inventory of DIC assuming conservative mixing between freshwater and marine end-members (i.e., from non-estuarine sources), and $\sum[\mathrm{DIC}]_{\text {gasex }}$ is the inventory of DIC lost to air-water gas exchange from the estuary, due to $p \mathrm{CO}_{2}$ in the water being above solubility equilibrium with the atmosphere (see Sect. 2.6). The freshwater and marine end-members were assigned to the values measured at the lowest (Tarpon Bay) and highest salinities, respectively.

The total $\mathrm{O}_{2}$ deficit in Shark River during the experiments was determined by examining the difference in $\mathrm{O}_{2}$ inventories for conservative mixing and actual measurements, correcting for $\mathrm{O}_{2}$ influx due to gas exchange using a formulation similar to Eq. (2) above (i.e., $\sum[\mathrm{DO}]_{\text {deficit }}=\sum[\mathrm{DO}]_{\text {conserv }}-$ $\left.\sum[\mathrm{DO}]_{\text {observed }}+\sum[\mathrm{DO}]_{\text {gasex }}\right)$.

\subsection{Air-water $\mathrm{O}_{2}$ and $\mathrm{CO}_{2}$ fluxes}

To enable comparison between different gases and different aquatic environments, it is customary to normalize gas transfer velocities to a Schmidt number ( $S c$; kinematic viscosity of water divided by diffusion coefficient of gas in water) of $600, k(600)$, corresponding to that of $\mathrm{CO}_{2}$ in freshwater at $20^{\circ}$ C. $k(600)$ for SharkTREx 1 and 2, determined from the wind speed and current velocity parameterization proposed in Ho et al. (2016), were $3.5 \pm 1.0$ and $4.2 \pm 1.8 \mathrm{~cm} \mathrm{~h}^{-1}$, respectively. To determine $k$ for $\mathrm{O}_{2}$ and $\mathrm{CO}_{2}$ at the temperature and salinity measured in the rivers, the following equation was used, assuming a $S c^{-1 / 2}$ scaling (Jähne et al., 1987):

$k_{\mathrm{O}_{2}}=k(600)\left(\frac{S c_{\mathrm{O}_{2}}}{600}\right)^{-1 / 2}$,

where $k$ and $S c$ of $\mathrm{CO}_{2}$ could be substituted in Eq. (3) for $\mathrm{O}_{2}$, and $\mathrm{Sc}$ for $\mathrm{O}_{2}$ and $\mathrm{CO}_{2}$ were calculated as a function of temperature and salinity using data compiled by Wanninkhof (2014).

Air-water $\mathrm{O}_{2}$ fluxes $\left(F_{\mathrm{O}_{2}} ; \mathrm{mmol} \mathrm{m}^{-2} \mathrm{~d}^{-1}\right)$ were calculated as follows:

$F_{\mathrm{O}_{2}}=k_{\mathrm{O}_{2}}\left(\mathrm{O}_{2_{\text {equil }}}-\mathrm{O}_{2}\right)$,

where $k_{\mathrm{O}_{2}}\left(\mathrm{~cm} \mathrm{~h}^{-1}\right)$ is the gas transfer velocity for $\mathrm{O}_{2}, \mathrm{O}_{2}$ equil $\left(\mathrm{mmol} \mathrm{m}{ }^{-3}\right)$ is the equilibrium concentration of $\mathrm{O}_{2}$ in the water at a given temperature and salinity (Garcia and Gordon, 1992), and $\mathrm{O}_{2}$ is the measured oxygen concentration in the water.

Similarly, air-water $\mathrm{CO}_{2}$ fluxes $\left(\mathrm{F}_{\mathrm{CO}_{2}} ; \mathrm{mmol} \mathrm{m}^{-2} \mathrm{~d}^{-1}\right)$, which were used to determine changes in DIC due to gas exchange, were calculated as follows:

$F_{\mathrm{CO}_{2}}=k_{\mathrm{CO}_{2}} K_{0} \Delta p \mathrm{CO}_{2}$,

where $k_{\mathrm{CO}_{2}}\left(\mathrm{~cm} \mathrm{~h}^{-1}\right)$ is the gas transfer velocity for $\mathrm{CO}_{2}$, $K_{0}\left(\mathrm{~mol} \mathrm{~atm}{ }^{-1} \mathrm{~m}^{-3}\right)$ is the aqueous-phase solubility of $\mathrm{CO}_{2}$ (Weiss, 1974), and $\Delta p \mathrm{CO}_{2}$ ( $\left.\mu \mathrm{atm}\right)$ is the difference between the measured $p \mathrm{CO}_{2}$ in air equilibrated with water and atmospheric $p \mathrm{CO}_{2}$.

As with the inventories, $F_{\mathrm{CO}_{2}}$ were separated into estuarine and non-estuarine contributions. Because of the nonlinearity in the relationship between $p \mathrm{CO}_{2}$ and other carbonate system parameters, the $p \mathrm{CO}_{2}$ in the river expected from conservative mixing was calculated by assuming conservative mixing for DIC and TAlk, and then calculating $p \mathrm{CO}_{2}$ using CO2SYS (Pierrot et al., 2006), with the dissociation constants of Cai and Wang (1998). Then, the non-estuarine $F_{\mathrm{CO}_{2}}$ was calculated as above with Eq. (5), and the $F_{\mathrm{CO}_{2}}$ attributed to estuarine sources was determined as the difference between total and non-estuarine $F_{\mathrm{CO}_{2}}$.

\subsection{Estuarine and mangrove contributions to DIC}

DIC in the Shark and Harney rivers may originate from several sources in addition to input from the freshwater marsh upstream and the coastal ocean, including (1) mangrove root respiration, (2) organic matter mineralization in sediments or in river water, (3) dissolution of $\mathrm{CaCO}_{3}$ in sediments or in river water, and (4) groundwater discharge. Groundwater in this region is likely to contain DIC from $\mathrm{CaCO}_{3}$ dissolution that occurs when saltwater intrudes into the karst aquifer that underlies this region (Price et al., 2006), as well as DIC from sediment organic matter mineralization. In this setting, the combination of no. 1 and no. 2 represents the mangrove source of DIC ([DIC $]_{\text {mangrove }}$ ), and the combination of no. 3 and no. 4 represents the $\mathrm{CaCO}_{3}$ dissolution source ([DIC $\left.]_{\text {dissolution }}\right)$ to estuarine [DIC]:

$$
\begin{aligned}
{[\mathrm{DIC}]_{\text {estuary }} } & =[\mathrm{DIC}]_{\text {observed }}-[\mathrm{DIC}]_{\text {conserv }}+[\mathrm{DIC}]_{\text {gasex }} \\
& =[\mathrm{DIC}]_{\text {mangrove }}+[\mathrm{DIC}]_{\text {dissolution }},
\end{aligned}
$$

where $[\mathrm{DIC}]_{\text {observed }}$ is the observed DIC concentration, $[\mathrm{DIC}]_{\text {conserv }}$ is the DIC concentration expected by conservative mixing of the two end-members, and [DIC $]_{\text {gasex }}$ is the correction for change in [DIC $]_{\text {observed }}$ due to loss through airwater gas exchange as the water transits through the estuary. [DIC] $]_{\text {gasex }}$ was determined from $F_{\mathrm{CO}_{2}}$ and the residence time of water during each experiment (Ho et al., 2016).

Measurements of $\delta^{13} \mathrm{C}_{\text {DIC }}$ and estuarine DIC / TAlk ratios were used to determine the mangrove sources to estuarine DIC. Fixation of $\mathrm{CO}_{2}$ through photosynthesis is neglected in both models as these rivers are characterized by low chlorophyll $a$ concentration and low phytoplankton biomass (Boyer et al., 1997). During SharkTREx 1 and 2, there was a negligible difference between $p \mathrm{CO}_{2}$ measured during the day and night (ca. $3 \%$ ). 


\subsubsection{Determining mangrove contribution from $\delta^{13} \mathrm{C}_{\text {DIC }}$}

Processes 1 through 4 listed above influence $\delta^{13} \mathrm{C}_{\mathrm{DIC}}$ in the estuary differently due to the differences in the $\delta^{13} \mathrm{C}$ values originating from respiration of mangrove-derived organic matter, and $\mathrm{CaCO}_{3}$ dissolution. The isotopic fractionation during respiration of organic matter is small, and the $\delta^{13} \mathrm{C}_{\text {DIC }}$ values produced via this pathway should be approximately equivalent to the $\delta^{13} \mathrm{C}$ of the organic matter respired (DeNiro and Epstein, 1978). The isotopic fractionation during dissolution/re-precipitation of $\mathrm{CaCO}_{3}$ is also considered to be negligible (Salomons and Mook, 1986).

The expected $\delta^{13} \mathrm{C}$ values of DIC in the rivers as a result of conservative mixing $\left(\delta^{13} \mathrm{C}_{\text {conserv }}\right)$ of the marine and freshwater end-members of the Shark and Harney rivers were calculated as follows (Mook and Tan, 1991):

$$
\begin{aligned}
& \delta^{13} \mathrm{C}_{\text {conserv }}= \\
& \frac{S\left([\mathrm{DIC}]_{\mathrm{F}} \delta^{13} \mathrm{C}_{\mathrm{F}}-[\mathrm{DIC}]_{\mathrm{M}} \delta^{13} \mathrm{C}_{\mathrm{M}}\right)+S_{\mathrm{F}}[\mathrm{DIC}]_{\mathrm{M}} \delta^{13} \mathrm{C}_{\mathrm{M}}-S_{\mathrm{M}}[\mathrm{DIC}]_{\mathrm{F}} \delta^{13} \mathrm{C}_{\mathrm{F}}}{S\left([\mathrm{DIC}]_{\mathrm{F}}-[\mathrm{DIC}]_{\mathrm{M}}\right)+S_{\mathrm{F}}[\mathrm{DIC}]_{\mathrm{M}}-S_{\mathrm{M}}[\mathrm{DIC}]_{\mathrm{F}}}
\end{aligned}
$$

where [DIC] is the observed DIC concentration, $S$ is the measured salinity, and $\mathrm{M}$ and $\mathrm{F}$ subscripts refer to the marine and freshwater end-members, respectively.

An estimate of the maximum contribution of $[\mathrm{DIC}]_{\text {mangrove }}$ and $[\mathrm{DIC}]_{\text {dissolution }}$ to $[\mathrm{DIC}]_{\text {estuary }}$ can be obtained by solving Eq. (6) and the following:

$$
\begin{aligned}
\delta^{13} \mathrm{C}_{\mathrm{DIC}} & \times[\mathrm{DIC}]_{\text {observed }}=\delta^{13} \mathrm{C}_{\text {conserv }} \times[\mathrm{DIC}]_{\text {conserv }} \\
& +\delta^{13} \mathrm{C}_{\text {mangrove }} \times[\mathrm{DIC}]_{\text {mangrove }}+\delta^{13} \mathrm{C}_{\text {dissolution }} \\
& \times[\mathrm{DIC}]_{\text {dissolution }}-\left(\delta^{13} \mathrm{C}_{\mathrm{DIC}}-\varepsilon_{13}\right) \\
& \times[\mathrm{DIC}]_{\text {gasex }},
\end{aligned}
$$

where the $\delta^{13} \mathrm{C}_{\text {conserv }}$ value is the DIC isotopic composition expected for conservative mixing (Mook and Tan, 1991), $\delta^{13} \mathrm{C}_{\text {mangrove }}$ is the isotopic composition for mangrovederived material ( $-30 \%$; Mancera-Pineda et al., 2009),

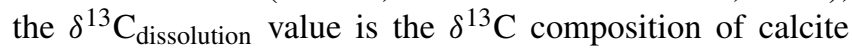
( $\sim 1 \%$ ), and $\varepsilon_{13}$ is the equilibrium isotope fractionation between DIC and $\mathrm{CO}_{2}$ gas ( $\sim 8 \%$; Zhang et al., 1995).

\subsubsection{Determining the mangrove contribution from TAlk / DIC}

An independent approach to separate the mangrove contribution from $\mathrm{CaCO}_{3}$ dissolution is to use the covariation of $[\mathrm{DIC}]_{\text {estuary }}$ and $[\mathrm{TAlk}]_{\text {estuary }}$ as an indicator of the biogeochemical processes affecting DIC dynamics (Borges et al., 2003; Bouillon et al., 2007c), as these processes have different effects on DIC and TAlk. Assuming that $[\mathrm{TAlk}]_{\text {estuary }}$ is mainly produced by the dissolution of $\mathrm{CaCO}_{3}$, [DIC] $]_{\text {dissolution }}$ can be determined as $0.5 \times[\text { TAlk }]_{\text {estuary }}$, and then $[\mathrm{DIC}]_{\text {mangrove }}$ can be calculated from Eq. (6). However, since sulfate reduction, a primary mineralization pathway in mangrove sediments, may also contribute to TAlk (Alongi, 1998; Alongi et al., 2005) this calculation represents an upper bound estimate for $[\mathrm{DIC}]_{\text {dissolution }}$ and a lower bound estimate for $[\mathrm{DIC}]_{\text {mangrove }}$.

\subsection{Determining the mangrove contribution to DOC}

In the Shark and Harney rivers, dissolved organic matter may be derived from upstream freshwater wetland species such as periphyton and sawgrass, from seagrass communities and marine phytoplankton, or from mangrove vegetation inside the estuary (Jaffe et al., 2001). The estuarine contributions to DOC ([DOC $\left.]_{\text {estuary }}\right)$ in the rivers was determined in the same way as for DIC above using Eq. (6), by substituting DOC for DIC accordingly, without the correction for gas exchange:

$[\mathrm{DOC}]_{\text {estuary }}=[\mathrm{DOC}]_{\mathrm{observed}}-[\mathrm{DOC}]_{\mathrm{conserv}}$,

where $[\mathrm{DOC}]_{\text {observed }}$ is the observed DOC concentration, and $[\mathrm{DOC}]_{\text {conserv }}$ is the DOC concentration expected from conservative mixing of the two end-members.

Then, measurements of $\delta^{13} \mathrm{C}_{\mathrm{DOC}}$ were made to ascertain the mangrove source of DOC in the river, in order to determine the proportion of [DOC $]_{\text {estuary }}$ that is of mangrove origin. The expected $\delta^{13} \mathrm{C}$ values of DOC as a result of conservative mixing $\left(\delta^{13} \mathrm{C}_{\text {conserv }}\right)$ were calculated using Eq. (7), substituting DOC for DIC. Assuming that [DOC] $]_{\text {estuary was }}$ entirely mangrove derived, $[\mathrm{DOC}]_{\text {mangrove }}$ should equal

$$
\begin{aligned}
& {[\mathrm{DOC}]_{\text {mangrove }}=} \\
& \frac{[\mathrm{DOC}]_{\text {observed }} \delta^{13} \mathrm{C}_{\mathrm{DOC}}+[\mathrm{DOC}]_{\text {conserv }} \delta^{13} \mathrm{C}_{\text {conserv }}}{\delta^{13} \mathrm{C}_{\text {mangrove }}},
\end{aligned}
$$

where $\delta^{13} \mathrm{C}_{\text {mangrove }}$ is the isotopic composition for mangrove-derived material $(-30 \%)$.

\subsection{Longitudinal dispersion}

The longitudinal $\mathrm{SF}_{6}$ distribution was corrected for tidal movement to slack water before ebb for each day using a method described in Ho et al. (2002). The absolute magnitudes of the average daily corrections were 2.0 and $2.7 \mathrm{~km}$ for SharkTREx 1 and 2, respectively, with a range for individual measurements of 0 to $5.8 \mathrm{~km}$ and 0 to $7.3 \mathrm{~km}$ for SharkTREx 1 and 2, respectively. Longitudinal dispersion coefficient $K_{x}$ $\left(\mathrm{m}^{2} \mathrm{~s}^{-1}\right)$ was calculated from the change of moment of the longitudinal $\mathrm{SF}_{6}$ distribution over time as follows (Fischer et al., 1979; Rutherford, 1994):

$$
K_{x}=\frac{1}{2}\left(\frac{\mathrm{d} \sigma_{x}^{2}}{\mathrm{~d} t}\right),
$$

where $\sigma_{x}^{2}$ is the second moment of the longitudinal $\mathrm{SF}_{6}$ distribution for each day.

\subsection{Longitudinal fluxes to the Gulf of Mexico}

The longitudinal fluxes of DIC and DOC from Shark and Harney rivers to the GOM were calculated using the averaged 


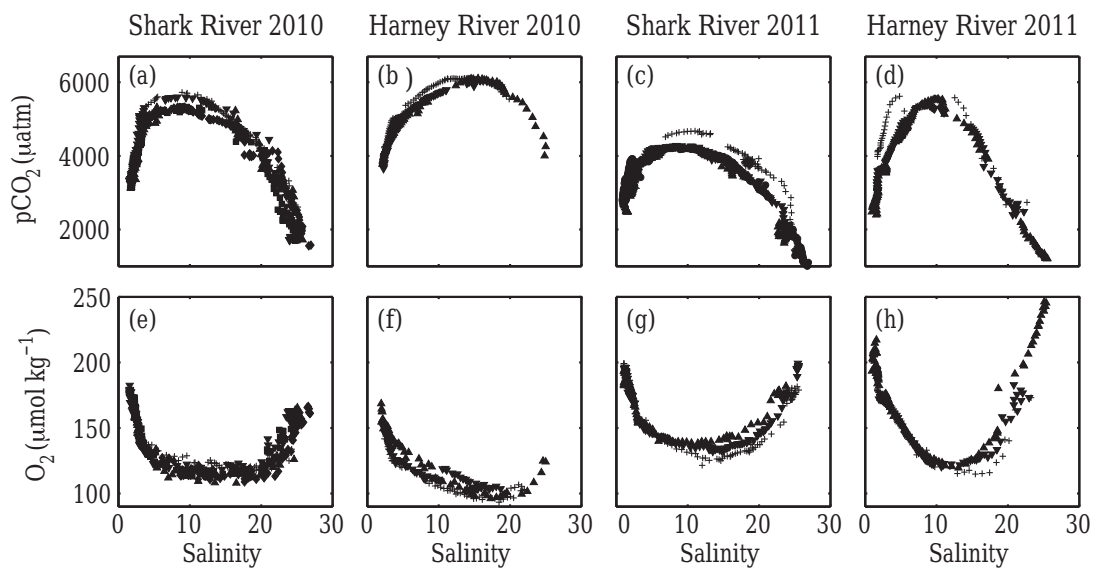

Figure 2. Distributions of $p \mathrm{CO}_{2}(\mathbf{a}-\mathbf{d})$ and dissolved $\mathrm{O}_{2}(\mathbf{e}-\mathbf{h})$ along the salinity gradient in the Shark and Harney rivers during the 2010 (SharkTREx 1) and 2011 (SharkTREx 2) campaigns. Different symbols represent measurements made on different days.

DIC or DOC inventories, and the residence time of water $(\tau$; d), which was determined from the decrease in the inventory of $\mathrm{SF}_{6}$ after correcting for air-water gas exchange (Ho et al., 2016). For example, the longitudinal DIC flux ( $F_{\text {DIC }}$; $\mathrm{mol} \mathrm{d}^{-1}$ ) can be calculated as follows (e.g., Dettmann, 2001):

$F_{\text {DIC }}=\frac{\sum[\text { DIC }]_{\text {observed }}}{\tau}$.

Equation (12) can be used to calculate the fluxes of any other dissolved or suspended substance in the river by substituting its inventory in place of DIC. In addition, using the estuarine and non-estuarine fractions of the inventories in Eq. (12) allowed the estuarine and non-estuarine proportions of the longitudinal carbon fluxes to be quantified.

The advantage of this method to calculate longitudinal flux in a tidal river over a method that uses net discharge and constituent concentration is that the effect of tidal flushing is implicitly accounted for by the residence time, and therefore there is not a need to explicitly define the fraction of river water in the return flow during each flood tide.

\section{Results and discussion}

\subsection{Distribution patterns and carbon inventories}

During SharkTREx 1, the salinity along the longitudinal transects ranged from 1.2 to 27.1 , and the mean $( \pm \mathrm{SD})$ water temperature was $23.4 \pm 0.2{ }^{\circ} \mathrm{C}(n=3767)$. During SharkTREx 2, salinity ranged from 0.6 to 27.1 , and water temperatures averaged $22.7 \pm 0.9^{\circ} \mathrm{C}(n=3818)$.

Both $p \mathrm{CO}_{2}$ and $\mathrm{DO}$ showed large spatial variability within the Shark and Harney rivers during SharkTREx 1 and 2 (Fig. 2). Measured $p \mathrm{CO}_{2}$ values were well above atmospheric equilibrium along the entire salinity range, with values ranging from ca. 1000 to $6200 \mu \mathrm{atm}$. Maximum $p \mathrm{CO}_{2}$ values were observed at intermediate salinities, decreasing towards both end-members, while DO showed the opposite pattern, with saturations ranging from 36 to $113 \%$.

The patterns of TAlk and DIC along the salinity gradient followed the same trend as $p \mathrm{CO}_{2}$ and were clearly non-conservative (Fig. 3a-f). TAlk varied between ca. 3400 and $5000 \mu \mathrm{mol} \mathrm{kg} \mathrm{kg}^{-1}$ during SharkTREx 1 and between ca. 3000 and $3900 \mu \mathrm{mol} \mathrm{kg}{ }^{-1}$ during SharkTREx 2. DIC ranged from ca. 3400 to $5100 \mu \mathrm{mol} \mathrm{kg}{ }^{-1}$ during SharkTREx 1, and ca. 2800 to $4000 \mu \mathrm{mol} \mathrm{kg}{ }^{-1}$ during SharkTREx $2 . \delta^{13} \mathrm{C}_{\text {DIC }}$ values ranged from -10.3 to $-6.6 \%$ and from -11.4 to $-5.8 \%$ during SharkTREx 1 and 2, respectively. Higher DIC, TAlk, and $p \mathrm{CO}_{2}$ coincided with lower $\mathrm{O}_{2}$ saturation, lower $\delta^{13} \mathrm{C}_{\mathrm{DIC}}$, and lower $\mathrm{pH}$ values (Fig. $3 \mathrm{~g}-\mathrm{i}$ ), indicative of mineralization of mangrove-derived organic matter within the estuary.

During SharkTREx 1, the DOC concentrations in the freshwater end-member were higher than SharkTREx 2 (Fig. 4). For both experiments, DOC concentrations followed a non-conservative pattern (see also Cawley et al., 2013), but this trend was less apparent during SharkTREx 1 compared to SharkTREx 2 (Fig. 4).

The inventories of DIC, DOC, DO, TAlk, and $p \mathrm{CO}_{2}$ were relatively constant in the Shark and Harney rivers, indicating quasi-steady-state conditions during SharkTREx 1 and 2. Under these conditions, carbon inputs and exports are balanced, and fluxes and concentrations may be examined interchangeably. $K_{x}$ during the experiments $(16.4 \pm 4.7$ and $77.3 \pm 6.5 \mathrm{~m}^{2} \mathrm{~s}^{-1}$ for Shark River during SharkTREx 1 and 2, respectively, and $136.1 \pm 16.5 \mathrm{~m}^{2} \mathrm{~s}^{-1}$ for Harney River during SharkTREx 2) were relatively large, and suggest that any perturbations (such as export of DIC from mangroves) would be quickly mixed thoroughly in the estuary.

In the following, for brevity, fluxes and inventories are summarized as ranges, which cover the two rivers and two experiments, so they reflect both temporal and spatial variability. The individual values are given in Tables 1 and 2 . 

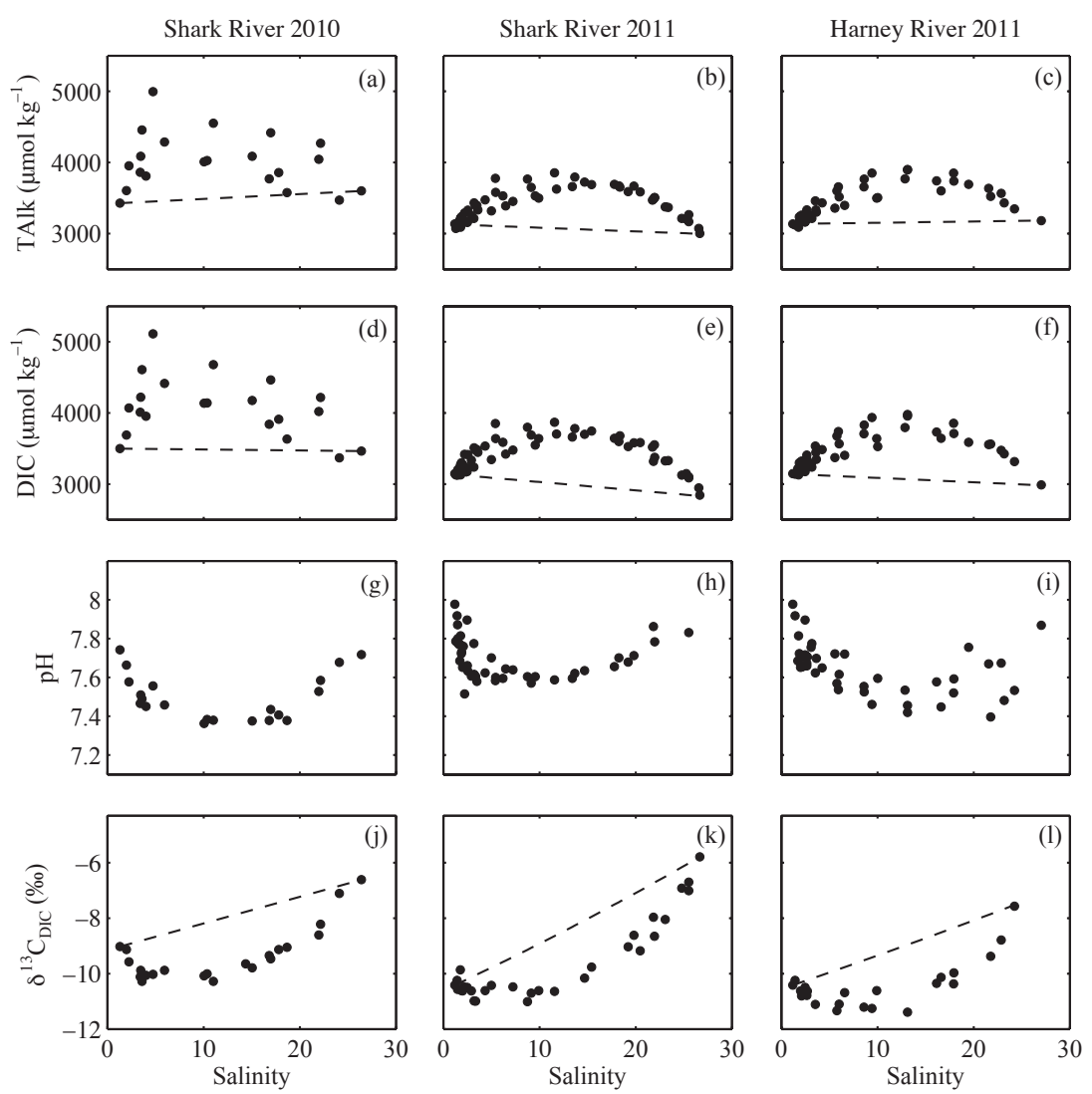

Figure 3. Distribution of TAlk (a-c), DIC $(\mathbf{d}-\mathbf{f}), \mathrm{pH}(\mathbf{g}-\mathbf{i})$, and $\delta^{13} \mathrm{C}_{\mathrm{DIC}}(\mathbf{j}-\mathbf{l})$ along the salinity gradient in the Shark and Harney rivers during the 2010 (SharkTREx 1) and 2011(SharkTREx 2) campaigns. During SharkTREx 1, TAlk and pH were measured at FIU, and DIC was calculated using CO2SYS (Pierrot et al., 2006). During SharkTREx 2, DIC and TAlk were measured at NOAA/AOML, and pH was calculated using CO2SYS. The dashed lines indicate the distribution expected for conservative mixing.
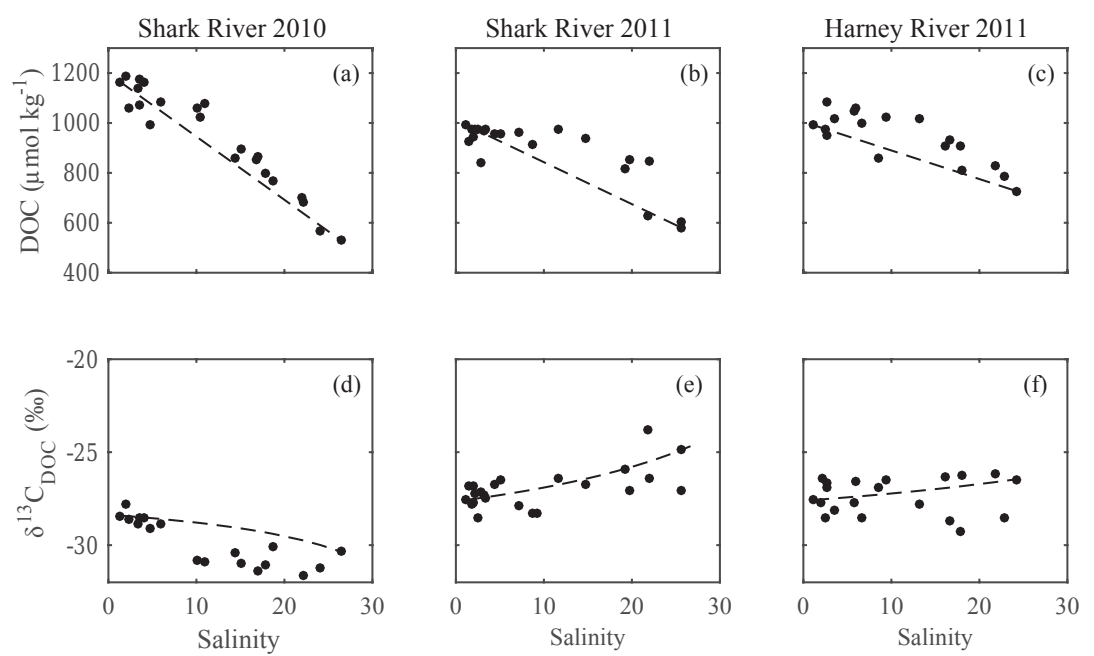

Figure 4. Distribution of DOC and $\delta^{13} \mathrm{C}_{\mathrm{DOC}}$ along the salinity gradient in the Shark and Harney rivers in samples collected during SharkTREx 1 and 2. The dashed lines indicate the distribution expected for conservative mixing. 


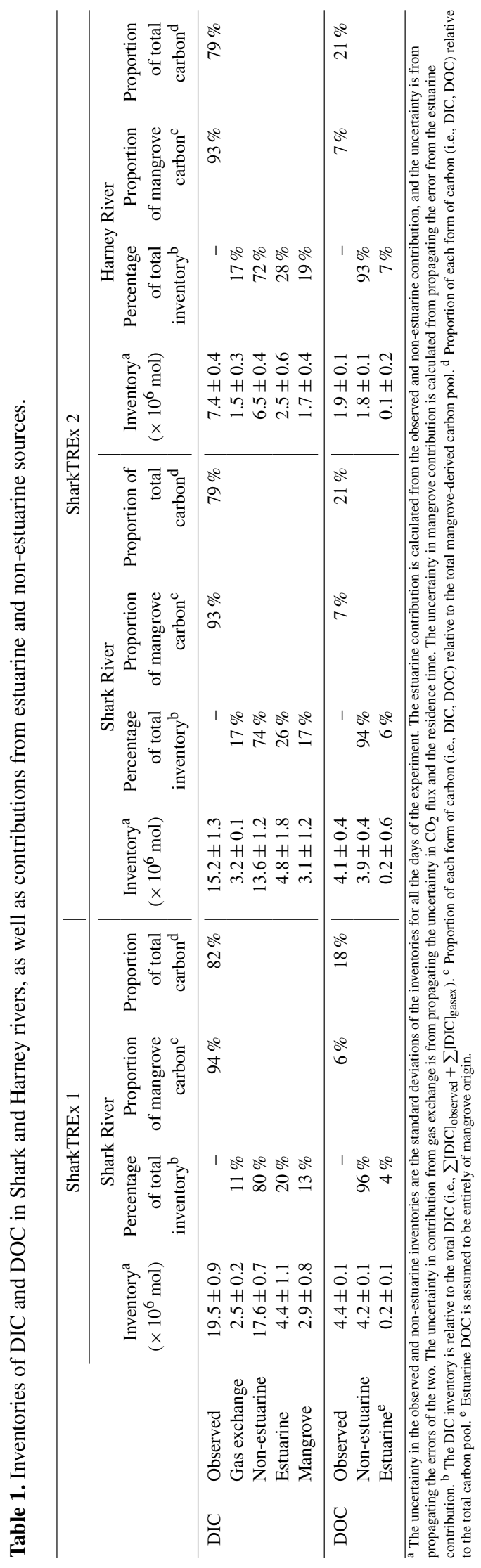

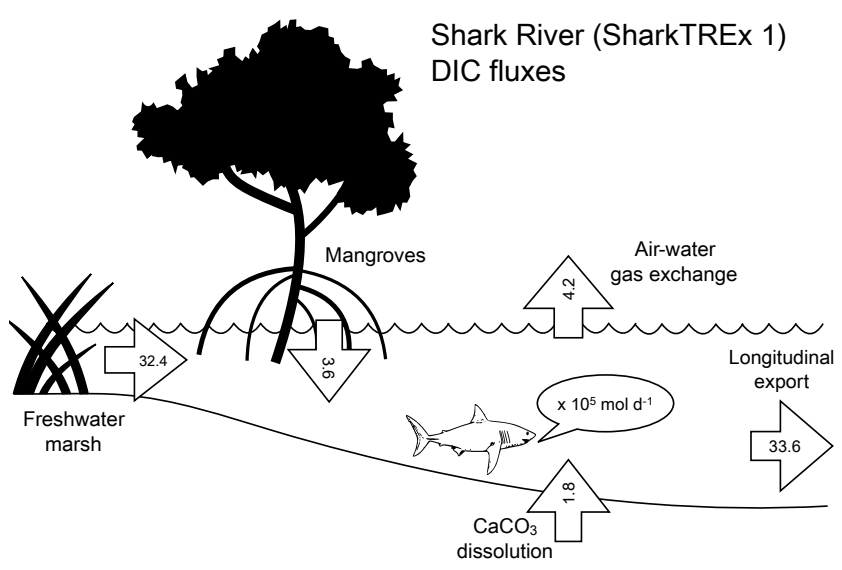
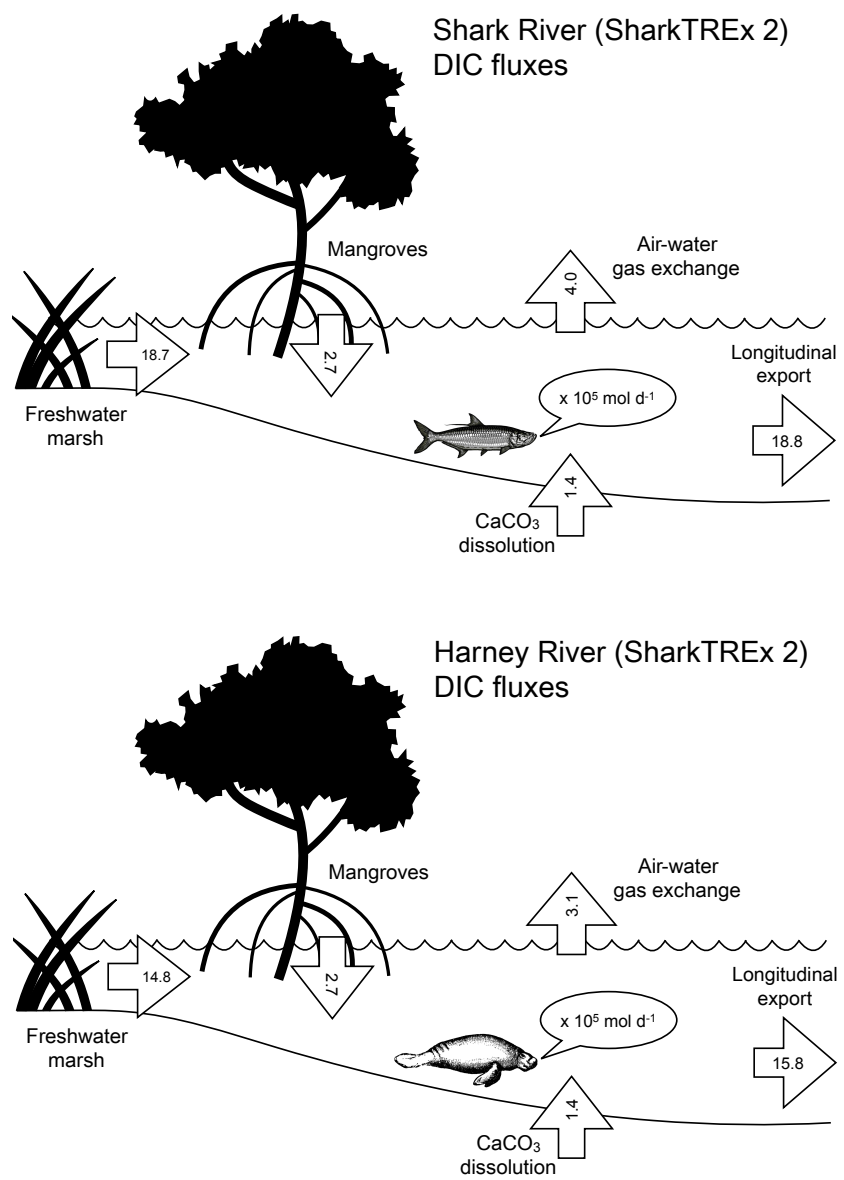

Figure 5. Diagrams showing the main DIC fluxes (in $10^{5} \mathrm{~mol} \mathrm{~d}^{-1}$ ) entering and exiting the Shark and Harney rivers during SharkTREx 1 and 2. Fluxes from the freshwater marsh were assumed to be fluxes estimated from the conservative DIC curves.

DIC was the dominant form of dissolved carbon in both rivers and accounted for 79 to $82 \%$ of the total dissolved carbon in the rivers. The contribution of DOC to the total carbon pool varied between 18 and $21 \%$ (Table 1). 
Table 2. Longitudinal DIC and DOC fluxes, and air-water $\mathrm{CO}_{2}$ fluxes for the Shark and Harney rivers during SharkTREx 1 and 2.

\begin{tabular}{|c|c|c|c|c|}
\hline & \multicolumn{2}{|c|}{ SharkTREx 1} & \multicolumn{2}{|c|}{ SharkTREx 2} \\
\hline & Shark River & Harney River & Shark River & Harney River \\
\hline \multicolumn{5}{|c|}{ Longitudinal DIC fluxes $\left(\times 10^{5} \mathrm{~mol} \mathrm{~d}^{-1}\right)^{\mathrm{a}}$} \\
\hline Total & $33.6 \pm 1.6$ & N/A & $18.8 \pm 1.6$ & $15.8 \pm 0.9$ \\
\hline Non-estuarine contribution & $30.3 \pm 1.1$ & N/A & $16.8 \pm 1.5$ & $13.7 \pm 0.8$ \\
\hline Estuarine contribution & $3.3 \pm 1.9$ & N/A & $2.0 \pm 2.2$ & $2.1 \pm 1.3$ \\
\hline Mangrove contribution & $2.2 \pm 1.3$ & N/A & $1.3 \pm 1.5$ & $1.4 \pm 0.8$ \\
\hline \multicolumn{5}{|c|}{ Air-water $\mathrm{CO}_{2}$ fluxes $\left(\times 10^{5} \mathrm{~mol} \mathrm{~d}^{-1}\right)^{\mathrm{a}}$} \\
\hline Total & $4.2 \pm 0.4$ & $4.1 \pm 0.2$ & $4.0 \pm 0.2$ & $3.1 \pm 0.6$ \\
\hline Non-estuarine contribution & $2.1 \pm 0.2$ & $2.0 \pm 0.1$ & $1.9 \pm 0.1$ & $1.1 \pm 0.2$ \\
\hline Estuarine contribution & $2.1 \pm 0.4$ & $2.1 \pm 0.3$ & $2.1 \pm 0.2$ & $2.0 \pm 0.6$ \\
\hline Mangrove contribution & $1.4 \pm 0.3$ & $1.4 \pm 0.2$ & $1.4 \pm 0.1$ & $1.3 \pm 0.4$ \\
\hline \multicolumn{5}{|c|}{ Longitudinal DOC fluxes $\left(\times 10^{5} \mathrm{~mol} \mathrm{~d}^{-1}\right)^{\mathrm{a}, \mathrm{b}}$} \\
\hline Total & $7.5 \pm 0.2$ & $3.3 \pm 0.4$ & $5.1 \pm 0.5$ & $4.2 \pm 0.2$ \\
\hline Non-estuarine contribution & $7.2 \pm 0.1$ & $2.6 \pm 0.3$ & $4.8 \pm 0.5$ & $3.9 \pm 0.2$ \\
\hline Estuarine contribution ${ }^{\mathrm{c}}$ & $0.3 \pm 0.2$ & $0.6 \pm 0.6$ & $0.3 \pm 0.7$ & $0.3 \pm 0.3$ \\
\hline
\end{tabular}

\subsection{Air-water $\mathrm{CO}_{2}$ fluxes}

As shown by Ho et al. (2014), $p \mathrm{CO}_{2}$ observed during SharkTREx 1 and 2 fall in the upper range of those reported in other estuarine (Borges, 2005) and mangrove-dominated systems (Bouillon et al., 2003, 2007a, b; Koné and Borges, 2008; Call et al., 2015). The mean air-water $\mathrm{CO}_{2}$ fluxes in Shark River for SharkTREx 1 and 2 were $105 \pm 9$ and $99 \pm 6 \mathrm{mmol} \mathrm{m}^{-2} \mathrm{~d}^{-1}$ (Ho et al., 2016). The analysis is taken further here by including data from Harney River. The mean air-water $\mathrm{CO}_{2}$ fluxes in Harney River were $150 \pm 8$ and $114 \pm 21 \mathrm{mmol} \mathrm{m}^{-2} \mathrm{~d}^{-1}$ for SharkTREx 1 and 2, respectively.

Borges et al. (2003) summarized all available $p \mathrm{CO}_{2}$ data from mangrove surrounding waters, and calculated $\mathrm{CO}_{2}$ fluxes to the atmosphere that averaged $50 \mathrm{mmol} \mathrm{m}^{-2} \mathrm{~d}^{-1}$ (with a range of 4.6 to $113.5 \mathrm{mmol} \mathrm{m}^{-2} \mathrm{~d}^{-1}$ ), and Bouillon et al. (2008a) estimated a global $\mathrm{CO}_{2}$ flux from mangroves of ca. $60 \pm 45 \mathrm{mmol} \mathrm{m}^{-2} \mathrm{~d}^{-1}$. One reason that the fluxes from SharkTREx 1 and 2 are on the upper end of those estimates may be that the Shark and Harney rivers receive a large input of DIC from the freshwater marsh upstream (Table 1), causing higher $p \mathrm{CO}_{2}$ in the estuary compared to the global average.

Scaling the air-water $\mathrm{CO}_{2}$ fluxes by the area of open water in the Shark and Harney rivers, where Tarpon Bay is included with Shark River, suggests that the total carbon emissions to the atmosphere through air-water gas exchange in Shark River was $4.2 \pm 0.4 \times 10^{5}$ and $4.0 \pm 0.2 \times 10^{5} \mathrm{~mol} \mathrm{~d}^{-1}$ during SharkTREx 1 and 2 , respectively, and were $4.1 \pm 0.2 \times 10^{5}$ and $3.1 \pm 0.6 \times 10^{5} \mathrm{~mol} \mathrm{~d}^{-1}$ from the Harney River during SharkTREx 1 and 2, respectively (Fig. 5), which is remarkably consistent, both spatially and temporally.

These fluxes were incorporated into the DIC mass balance of the Shark and Harney rivers (Eq. 2) by calculating the total $\mathrm{CO}_{2}$ degassed over the residence time of water in the rivers. Given the mean air-water $\mathrm{CO}_{2}$ fluxes (Table 2), the total $\mathrm{CO}_{2}$ degassed in the Shark River represents approximately 13 and $21 \%$ of $\sum[D I C]_{\text {observed }}$ during SharkTREx 1 and 2, respectively, and the $\mathrm{CO}_{2}$ degassed from the Harney River during SharkTREx 2 represents $20 \%$ of $\sum[D I C]_{\text {observed }}$, indicating that air-water $\mathrm{CO}_{2}$ exchange removes a non-negligible fraction of the inorganic carbon in these rivers. Exclusion of $\sum[D I C]_{\text {gasex }}$ from the mass balance in Eq. (2) would lead to an underestimation of $\sum[D I C]_{\text {estuary }}$ of between 33 and $44 \%$.

\subsection{Mangrove contribution to DIC inventory}

The highest DIC concentrations were correlated with low DO (Fig. 2) and characterized by ${ }^{13} \mathrm{C}$ depletion (Fig. 3j, k, l). Observations of elevated DIC and $p \mathrm{CO}_{2}$ in the middle of the estuary, coupled with $\delta^{13} \mathrm{C}_{\text {DIC }}$ and $\mathrm{O}_{2}$ depletion may indicate the importance, noted by other authors, of lateral transport of pore water from the peat-based mangrove forest into the river via tidal pumping (Bouillon et al., 2008a; Maher et al., 
Table 3. Mangrove contribution to $\sum[\mathrm{DIC}]_{\text {estuary }}$ determined from $\delta^{13} \mathrm{C}_{\text {DIC }}$ mass balance and TAlk / DIC ratios.

\begin{tabular}{lrrr}
\hline \multirow{2}{*}{ River } & Experiment & \multicolumn{2}{c}{ Methods } \\
\cline { 3 - 4 } & & $\delta^{13} \mathrm{C}_{\text {DIC }}$ & TAlk / DIC \\
\hline \multirow{2}{*}{ Shark River } & SharkTREx 1 & $60 \pm 6 \%$ & $70 \pm 3 \%$ \\
& SharkTREx 2 & $61 \pm 6 \%$ & $70 \pm 3 \%$ \\
Harney River & SharkTREx 1 & - & - \\
& SharkTREx 2 & $61 \pm 6 \%$ & $70 \pm 2 \%$ \\
\hline
\end{tabular}

2013). However, as demonstrated below, the observed DIC and $\delta^{13} \mathrm{C}_{\text {DIC }}$ distributions in these rivers cannot be explained solely by mineralization of mangrove-derived organic carbon.

\subsubsection{Evidence from $\delta^{13} \mathrm{C}_{\text {DIC }}$}

The distributions of DIC and $\delta^{13} \mathrm{C}_{\mathrm{DIC}}$ cannot be explained solely by the addition of mangrove-derived DIC and airwater gas exchange. Solving Eq. (8) for $\delta^{13} \mathrm{C}_{\mathrm{DIC}}$, assuming that $[\mathrm{DIC}]_{\text {dissolution }}$ is negligible and that the only source of DIC in the rivers is of mangrove origin, would result in $\delta^{13} \mathrm{C}$ values significantly lower than those observed. The low $\mathrm{pH}$ in interstitial waters of mangrove sediments due to organic matter mineralization processes may be favorable to $\mathrm{CaCO}_{3}$ dissolution in mangrove sediments, and this process could have an effect on estuarine $\delta^{13} \mathrm{C}_{\text {DIC }}$. Groundwater discharge could also influence DIC and $\delta^{13} \mathrm{C}_{\text {DIC. }}$. Inputs of DIC derived from $\mathrm{CaCO}_{3}$ dissolution from either of these sources may explain the differences in observed $\delta^{13} \mathrm{C}_{\mathrm{DIC}}$ and those expected if [DIC $]_{\text {estuary }}$ was entirely of mangrove origin.

Solving Eqs. (6) and (8), the mineralization of mangrovederived organic matter is estimated to account for ca. $60 \pm 6 \%$ of $\sum[\text { DIC }]_{\text {estuary }}$ (Table 3 ), with the remainder originating from the dissolution of $\mathrm{CaCO}_{3}$. This estimate is sensitive to the end-member value chosen for $\delta^{13} \mathrm{C}_{\text {mangroves }}$ and $\delta^{13} \mathrm{C}_{\text {dissolution. }}$. For instance, if $\delta^{13} \mathrm{C}_{\text {mangroves }}$ were $-29 \%$ instead of $-30 \%$, the mangrove contribution would increase to $62 \%$.

\subsubsection{Evidence from DIC and TAlk}

In the Shark and Harney rivers, the high correlation $\left(r^{2}=\right.$ 0.99; Fig. 6) between [DIC] $]_{\text {estuary }}$ and [TAlk] estuary indicates the same processes control the inputs of DIC and TAlk to these rivers. By examining the covariation of [DIC $]_{\text {estuary }}$ and [TAlk] estuary, mangroves were found to contribute a minimum of $70 \pm 3 \%$ of $\sum[\text { DIC] }]_{\text {estuary }}$ (Table 3), with the remainder due to the dissolution of $\mathrm{CaCO}_{3}$. These estimates are in reasonable agreement with those based on the carbon isotopic mass balance.

The [TAlk] estuary vs. [DIC] $]_{\text {estuary }}$ ratios were 0.84 and 0.92 for Shark River during SharkTREx 1 and 2, and 0.90 for the

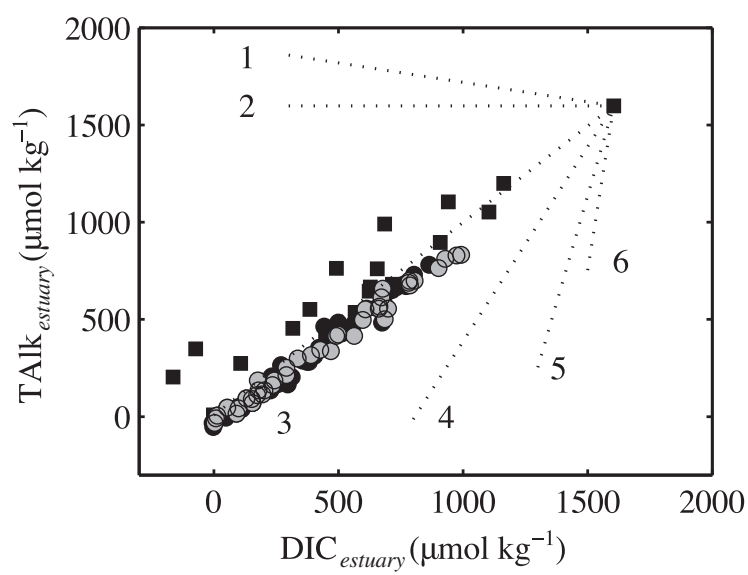

Figure 6. (a) Covariation of $\mathrm{DIC}_{\mathrm{estuary}}$ and $\mathrm{TAlk}_{\mathrm{estuary}}$. Black squares are samples from the Shark River during SharkTREx 1, and black and gray circles are from the Shark and Harney rivers, respectively, during SharkTREx 2. Dotted lines represent the theoretical covariation of DIC and TAlk for different biogeochemical processes: (1) aerobic respiration; (2) $\mathrm{CO}_{2}$ emission, (3) sulfate reduction, (4) $\mathrm{CaCO}_{3}$ dissolution, (5) manganese reduction, and (6) iron reduction.

Harney River during SharkTREx 2 (Fig. 6). The TAlk to DIC ratios for $\mathrm{CaCO}_{3}$ dissolution, sulfate reduction, and aerobic respiration are $-0.2,0.99$, and 2, respectively. Hence, in order to achieve the observed ratios, and given the estimated contribution of $\mathrm{CaCO}_{3}$ dissolution to $\sum[\mathrm{DIC}]_{\text {estuary }}$ of ca. $30 \%$, sulfate reduction and aerobic respiration were estimated to contribute 32 to 39 and 31 to $38 \%$, respectively.

\subsubsection{Evidence from DO}

The deficit of $\mathrm{O}_{2}$ in Shark River was found to be $2.7 \pm 0.7 \times 10^{6}$ and $3.7 \pm 0.3 \times 10^{6} \mathrm{~mol}$ during SharkTREx 1 and 2, respectively. Assuming a stoichiometric ratio of ca. 1.1 for $\mathrm{O}_{2}$ to $\mathrm{CO}_{2}$ during degradation/remineralization of terrestrial organic matter (Severinghaus, 1995; Keeling and Manning, 2014), the maximum contribution of aerobic respiration to the DIC added to the estuary was estimated to be 57 to $69 \%$. However, $\mathrm{O}_{2}$ may also be consumed during oxidation of reduced products from anaerobic metabolism, such as $\mathrm{H}_{2} \mathrm{~S}, \mathrm{Mn}^{2+}$ or $\mathrm{Fe}^{2+}$, with similar $\mathrm{O}_{2}$ to $\mathrm{CO}_{2}$ stoichiometry as aerobic respiration. Hence, the numbers derived above represent an upper limit for aerobic respiration, and if there were complete re-oxidation of metabolites from anaerobic respiration, the $\mathrm{O}_{2}$ deficit would represent total mineralization of terrestrial organic matter instead of just aerobic respiration. The mangrove contributions estimated from $\delta^{13} \mathrm{C}_{\text {DIC }}$ (Sect. 3.3.1) and TAlk / DIC (Sect. 3.3.2) are consistent with this analysis of the $\mathrm{O}_{2}$ deficit, which indicates that a minimum of $57-69 \%$ of $\sum[D I C]_{\text {estuary }}$ derived from the mineralization of organic matter. 


\subsection{Mangrove contributions to DOC inventory}

During both experiments, the $\delta^{13} \mathrm{C}_{\mathrm{DOC}}$ was highly depleted, indicative of contribution from higher plants, including mangroves. During SharkTREx 1, the lowest observed $\delta^{13} \mathrm{C}_{\mathrm{DOC}}$ value $(-31.6 \%$ o $)$ was in the mid-estuary (i.e., from salinity of ca. 10 to 20) (Fig. 4d). Previous studies of DOC from mangrove-dominated systems have reported values as low as $-30.4 \%$ o (Dittmar et al., 2006), and some of the more depleted samples from SharkTREx 1 might have DOC sourced from algae associated with mangrove roots, which can have relatively depleted values (Kieckbusch et al., 2004). The overall $\delta^{13} \mathrm{C}_{\mathrm{DOC}}$ depletion was less during SharkTREx 2, and the overall distribution was indicative of a stronger marine influence and/or mixing (Fig. 4e, f). The marine end-member had a more enriched $\delta^{13} \mathrm{C}_{\mathrm{DOC}}$, indicating a greater contribution of seagrass and/or marine phytoplankton-derived organic matter to the marine DOC pool (Anderson and Fourqurean, 2003). These observations are consistent with the greater longitudinal dispersion observed during SharkTREx 2 compared to SharkTREx 1.

The calculations of mangrove contribution using $\delta^{13} \mathrm{C}_{\mathrm{DOC}}$ mass balances (Eq. 10) also suggest that the majority of $[D O C]_{\text {estuary }}$, but only a small percentage of the total DOC inventory, was derived from mangroves $(7$ and $5 \%$ in the Shark River during SharkTREx 1 and 2, and $7 \%$ in the Harney River during SharkTREx 2).

\subsection{Longitudinal fluxes to the Gulf of Mexico and comparison with previous studies}

Residence times of Shark River (including Tarpon Bay) for SharkTREx 1 and 2 were, $5.8 \pm 0.4$ and $8.1 \pm 1.1$ days, respectively (Ho et al., 2016), and that of Harney River was $4.7 \pm 0.7$ days for SharkTREx 2. The resulting longitudinal DIC fluxes to the Gulf of Mexico (15.8 to $33.6 \times 10^{5} \mathrm{~mol} \mathrm{~d}^{-1}$ ) were significantly larger than the longitudinal DOC fluxes $\left(3.3\right.$ to $7.5 \times 10^{5} \mathrm{~mol} \mathrm{~d}^{-1}$ ) at salinity of ca. 27 (Fig. 5; Table 2).

There are no previously published DIC inventories or fluxes for the Shark and Harney rivers, so comparison with previous studies is focused on the DOC results. The DOC flux from the Shark River to the coastal ocean in SharkTREx $1\left(7.5 \pm 0.2 \times 10^{5} \mathrm{~mol} \mathrm{~d}^{-1}\right)$ is in very good agreement to that estimated by Bergamaschi et al. (2011) in an experiment conducted in the Shark River from 20 to 30 September 2010 $\left(7.6 \pm 0.5 \times 10^{5} \mathrm{~mol} \mathrm{~d}^{-1}\right)$. However, the net discharge during the Bergamaschi et al. (2011) study was higher than SharkTREx 1 (mean \pm SD: $9.1 \pm 7.1$ vs. $6.9 \pm 5.3 \mathrm{~m}^{3} \mathrm{~s}^{-1}$ ), which would lead to a shorter residence time of 4.6 days using a relationship presented in Ho et al. (2016). Using the DOC concentration data presented in Bergamaschi et al. (2011) yields an inventory that is ca. 3\% higher than the DOC inventory in Shark River during SharkTREx 1. Calculations using the shorter residence time and higher DOC inventory yields a DOC flux of $9.7 \pm 0.2 \times 10^{5} \mathrm{~mol} \mathrm{~d}^{-1}$, which is ca. $30 \%$ higher than the estimates of Bergamaschi et al. (2011).

The longitudinal flux of mangrove-derived DOC from Shark River during SharkTREx $1\left(0.3 \pm 0.2 \times 10^{5} \mathrm{~mol} \mathrm{~d}^{-1}\right.$; Table 2) is in rough agreement with the estimate of Cawley et al. (2013) during the same period $\left(0.2 \times 10^{5} \mathrm{~mol} \mathrm{~d}^{-1}\right)$, but the value for Harney River $\left(0.6 \pm 0.6 \times 10^{5} \mathrm{~mol} \mathrm{~d}^{-1}\right)$ is lower than their estimate $\left(1.6 \times 10^{5} \mathrm{~mol} \mathrm{~d}^{-1}\right)$.

Mangroves contributed 4 to $6 \%$ of the total longitudinal DOC flux in the Shark River and $7 \%$ in the Harney River during SharkTREx 2 (Tables 1 and 4). Cawley et al. (2013), estimated a mangrove contribution to DOC flux of $3 \pm 10 \%$ for Shark River and $21 \pm 8 \%$ for the Harney River during November 2010, the same time period as SharkTREx 1. DOC measurements were not made in Harney River as part of SharkTREx 1. However, using the November 2010 DOC data from Harney River collected by Cawley et al. (2013) for inventory calculations, along with residence time derived from the tracers, a mangrove contribution of $19 \%$ to the total DOC longitudinal flux to the Gulf of Mexico was obtained.

\subsection{Distribution of carbon fluxes}

During SharkTREx 1 and 2, $\sum$ [DIC $]_{\text {estuary }}$ made up 20-28\% of the total DIC in the rivers, and $\sum[D O C]_{\text {estuary }}$ made up only 4 to $7 \%$ of the total DOC in the rivers. Mangroves are estimated to contribute 13 to $19 \%$ to the total DIC inventory. In all cases, the mangrove contribution to the DIC inventory is a factor of 3 greater than the mangrove contribution to the DOC inventory (Table 1).

During SharkTREx 1 and 2, the inventory of mangrovederived DIC exceeded that of DOC by a factor of 15 to 17 , which supports the idea that a large fraction of the carbon exported by mangroves to surrounding water is as DIC (Bouillon et al., 2008a), but is considerably larger than the estimates of ca. 3 to 10 compiled by Bouillon et al. (2008a) for mangroves at five sites in Asia and Africa.

The total dissolved carbon fluxes from all sources (i.e., freshwater wetland, mangrove, carbonate dissolution, and marine input) out of the Shark and Harney rivers during SharkTREx 1 and 2 are dominated by inorganic carbon (82$83 \%$; see Tables 2 and 4), either via air-water $\mathrm{CO}_{2}$ exchange or longitudinal flux of DIC to the coastal ocean (Fig. 5). The remaining $17-18 \%$ of the export is as DOC. This proportioning is remarkably similar between SharkTREx 1 and 2, and between the Shark and Harney rivers (Table 1). The estuarine contribution to these fluxes is relatively small (generally $<15 \%$ ), with the exception of air-water $\mathrm{CO}_{2}$ flux, where the estuary contribution was 49 to $63 \%$ (Table 4 ).

In this study, the particulate organic carbon (POC) flux was not examined. However, He et al. (2014) estimated the mangrove-derived POC flux in Shark River by taking the total volume discharge from the five major rivers along the southwest coast of Everglades National Park from 2004 to 2008 , and assuming that Shark River contributed $14 \%$ to the 
Table 4. Distribution of total and mangrove fluxes of DIC and DOC for Shark and Harney rivers during SharkTREx 1 and 2.

\begin{tabular}{|c|c|c|c|c|c|}
\hline & & $\begin{array}{l}\text { SharkTREx } \\
\text { experiment no. }\end{array}$ & $\begin{array}{r}\text { Estuarine } \\
\text { contribution }^{\mathrm{a}}\end{array}$ & $\begin{array}{l}\text { Percent of total } \\
\text { export flux }\end{array}$ & $\begin{array}{l}\text { Percent of total } \\
\text { mangroves flux }\end{array}$ \\
\hline \multirow[t]{4}{*}{ Longitudinal DIC flux } & Shark River & 1 & $10 \%$ & $74 \%$ & $57 \%$ \\
\hline & & 2 & $11 \%$ & $67 \%$ & $45 \%$ \\
\hline & Harney River & 1 & - & - & - \\
\hline & & 2 & $13 \%$ & $68 \%$ & $48 \%$ \\
\hline \multirow[t]{4}{*}{ Air-water $\mathrm{CO}_{2}$ flux } & Shark River & 1 & $49 \%$ & $9 \%$ & $35 \%$ \\
\hline & & 2 & $52 \%$ & $14 \%$ & $45 \%$ \\
\hline & Harney River & 1 & $51 \%$ & - & - \\
\hline & & 2 & $63 \%$ & $14 \%$ & $43 \%$ \\
\hline \multirow[t]{4}{*}{ All DIC fluxes } & Shark River & 1 & - & $83 \%$ & $92 \%$ \\
\hline & & 2 & - & $82 \%$ & $90 \%$ \\
\hline & Harney River & 1 & - & - & - \\
\hline & & 2 & - & $82 \%$ & $91 \%$ \\
\hline \multirow[t]{4}{*}{ Longitudinal DOC flux } & Shark River & 1 & $4 \%$ & $17 \%$ & $8 \%$ \\
\hline & & 2 & $6 \%$ & $18 \%$ & $10 \%$ \\
\hline & Harney River & 1 & $19 \%$ & - & - \\
\hline & & 2 & $7 \%$ & $18 \%$ & $9 \%$ \\
\hline
\end{tabular}

${ }^{a}$ Estuarine contribution to the individual fluxes in each river during each experiment. ${ }^{b}$ Flux as a percentage of the total dissolved carbon flux (i.e., longitudinal DIC, DOC, and air-water $\mathrm{CO}_{2}$ fluxes). ${ }^{\mathrm{c}}$ Flux as a percentage of the total mangrove-derived dissolved carbon flux (i.e., longitudinal DIC, DOC, and air-water $\mathrm{CO}_{2}$ fluxes).

mean annual discharge. They then multiplied this discharge by the average POM concentration $\left(5.20 \pm 0.614 \mathrm{mg} \mathrm{L}^{-1}\right)$ in the middle of the estuary to yield an annual POM flux from Shark River. Based on analysis of organic matter biomarkers, He et al. (2014) estimated that mangrove-derived POM was $70-90 \%$ of the total POM pool in the Shark River. Using this contribution and further assuming that $58 \%$ of POM weight is POC (Howard, 1965), they estimated a POC flux of 1.0 to $2.2 \times 10^{4} \mathrm{~mol} \mathrm{~d}^{-1}$. Because this estimate was based on biomarker and POM data from the mid-estuary, where the POM concentration and the mangrove contribution to POM are both likely to be much higher than either toward the freshwater end-member or the marine end-member, it is likely an overestimate of the mangrove-derived POC flux. Nevertheless, the mangrove-derived POC flux determined by He et al. (2014) is still only a small fraction (3 to 7\%) of the mangrove-derived dissolved carbon fluxes in Shark River during SharkTREx 1 and 2.

\subsection{Mangrove contributing area and estuary carbon balance}

One of the challenges of relating the results reported here to other studies is to scale the results to a mangrove contributing area, and thereby relate the findings to mangrove forest carbon balance, typically expressed on an aerial basis. Estimates of forest carbon export derived here are compared with other investigations in this estuary. The entire area of mangroves surrounding the Shark and Harney rivers region is ca. $111 \mathrm{~km}^{2}$, and the water area is ca. $17.5 \mathrm{~km}^{2}$ (Ho et al., 2014). Scaling the forest area by the water area of Shark River $\left(2.5 \mathrm{~km}^{2}\right)$ yields an associated forest area of $15.9 \mathrm{~km}^{2}$. The forest area associated with Harney River $\left(2.8 \mathrm{~km}^{2}\right)$ is $17.4 \mathrm{~km}^{2}$.

Using the total forest area associated with Shark River to scale estimates of total export of mangrove-derived carbon (the combination of longitudinal fluxes and air-water gas exchange) suggests an average dissolved carbon lateral export rate from the forest of 18.9 to $24.5 \mathrm{mmol} \mathrm{m}^{-2} \mathrm{~d}^{-1}$, including both DIC and DOC. However, since it is unknown what fraction of the total forest area associated with these rivers exported dissolved carbon through tidal pumping (a function of tidal height and duration), this is considered to be a minimum estimate. Average water levels at high tide during SharkTREx 1 and 2 at the USGS Shark River station were 88 and $95 \%$ of maximum wet season water levels reported at this site over the period from November 2007 to December 2012 (U.S. Geological Survey, 2016), and 12 inundation events occurred during both SharkTREx 1 and 2 . Water levels in the main river channel at the USGS Shark River station were above an estimate of the average minimum ground surface elevation derived from nearby groundwater monitoring wells in the estuary (sites $\mathrm{SH} 3$ and $\mathrm{SH} 4$; http://sofia.usgs.gov/eden/stationlist.php) for 21 and $28 \%$ of the time during the SharkTREx 1 and 2 experimental periods, 
respectively. These values indicate the export of dissolved carbon from flooded portions of the forest during the discontinuous inundation periods should be significantly greater than the dissolved carbon lateral export rate derived above in order to produce the observed inventories of mangrovederived dissolved carbon in the main channel.

Bergamaschi et al. (2011) proposed an annual total DOC export from the forest surrounding Shark River of $15.1 \pm 1.1 \mathrm{~mol} \mathrm{~m}^{-2} \mathrm{yr}^{-1}$ and describe their method of calculating contributing area using a model based on the relationship between discharge volume and changes in water levels during tidal cycles. They do not provide a contributing area, but this can be calculated from their results. They determined longitudinal DOC fluxes of $7.6 \pm 0.5 \times 10^{5}$ and $1.3 \pm 0.02 \times 10^{5} \mathrm{~mol} \mathrm{~d}^{-1}$ for the wet and dry seasons, respectively, and assumed that they are entirely of mangrove origin. Given the lengths of the wet and dry seasons, this would yield a mean annual DOC flux of $3.9 \pm 0.2 \times 10^{5} \mathrm{~mol} \mathrm{~d}^{-1}$, and $9.4 \pm 0.7 \mathrm{~km}^{2}$ of mangrove forest contributing to carbon fluxes through tidal flushing in this segment of Shark River. However, data from SharkTREx 1 and 2 indicate that ca. $5 \%$ of the total longitudinal DOC fluxes were of mangrove origin, with an average mangrovederived DIC to DOC flux ratio of 10.5. Using this information, the Bergamaschi et al. (2011) results were recalculated to yield a wet season dissolved carbon lateral export rate of $46.5 \pm 4.4 \mathrm{mmol} \mathrm{m}^{-2} \mathrm{~d}^{-1}$ (as DIC and DOC) from the forest.

Another method of estimating forest lateral carbon export utilizes the difference between measurements of net ecosystem-atmosphere $\mathrm{CO}_{2}$ exchange (NEE) above the mangrove forest surrounding Shark River $\left(267 \pm 15 \mathrm{mmol} \mathrm{m}^{-2} \mathrm{yr}^{-1}\right.$ in 2004; (Barr et al., 2012) and corresponding measures of net ecosystem carbon balance (NECB; $227 \pm 14 \mathrm{mmol} \mathrm{m}^{-2} \mathrm{~d}^{-1}$ ). NECB in 2004 can be estimated as the sum of carbon in litter fall $\left(104 \pm 8 \mathrm{mmol} \mathrm{m}^{-2} \mathrm{~d}^{-1}\right)$, wood production (44 $\pm 3 \mathrm{mmol} \mathrm{m}^{-2} \mathrm{~d}^{-1}$ ) (Castañeda-Moya et al., 2013), root growth $\left(47 \pm 11 \mathrm{mmol} \mathrm{m}^{-2} \mathrm{~d}^{-1}\right)$ (Castañeda-Moya et al., 2011), and soil carbon accumulation $\left(31.7 \mathrm{mmol} \mathrm{m}^{-2} \mathrm{~d}^{-1}\right)$ (Breithaupt et al., 2014) measured at the same location (FCE LTER site SRS6) in this forest. The difference between NEE and NECB $\left(40 \pm 17 \mathrm{mmol} \mathrm{m}^{-2} \mathrm{~d}^{-1}\right)$ provides an estimate of the annual rate of forest carbon export to Shark River on a daily basis (Chapin et al., 2006).

The rate of mangrove-derived carbon exported to estuarine waters is likely to vary over space and time, as a result of factors that include tidal cycles, phenology, and forest and soil structural characteristics. For example, Bergamaschi et al. (2011) found that DOC fluxes were 6 times higher during the wet season (September) than the dry season (April), whereas Cawley et al. (2013) found that the DOC fluxes were 4 and 10 times higher during the wet vs. dry season (November vs. March) in the Shark and Harney rivers, respectively. Barr et al. (2013) showed that forest respiration rates derived from NEE data are greater during the wet than dry seasons.
Higher respiration rates combined with increased inundation during the wet compared to dry seasons suggest that wet season DIC export will also be greater than dry season values. For these reasons, the annual carbon export rates derived from the difference between NECB and NEE are expect to underestimate wet season values. If annual lateral carbon export rates are considered as equivalent to a time-weighted sum of dry season (7 months) and wet season (5 months) values (after Bergamaschi et al., 2011), and wet season export is assumed to be, for example, 5 times greater than dry season values, the seasonal export rates $\left(15\right.$ and $75 \mathrm{mmol} \mathrm{m}^{-2} \mathrm{~d}^{-1}$ for dry and wet seasons, respectively) that correspond with the difference between annual NECB and NEE can be calculated.

The discrepancies between the estimates of carbon export rates derived here, and those derived from Bergamaschi et al. (2011) and the difference between NEE and NECB point out the need for additional studies to reduce the uncertainty in the relationships between riverine carbon fluxes, forest carbon export, and estimates of contributing areas. For example, Bergamaschi et al. (2011) conducted an Eulerian study at a single location in the middle of the estuary, where the mangrove influence might be higher than the Lagrangian study conducted during SharkTREx 1 and 2, which covered the entire estuary. Also, the estimate of forest carbon export based on the difference between NEE and NECB is from a single location along Shark River (at FCE LTER site SRS6), and may not be representative of the entire forest. Furthermore, forest lateral carbon export rates and contributing areas should be considered dynamic, varying over semi-diurnal timescales with the extent and duration of inundation during individual tidal cycles. The correct interpretation of a single, static value for contributing area such as derived above is therefore uncertain, since the tracer-based results represent an integration of carbon sources and sinks calculated over the water residence time and expressed on daily timescales. To improve understanding of how mangrove forest carbon balance and export influence riverine carbon inventories and fluxes to the Gulf of Mexico in this system, wet and dry season measurements over multiple years, information on the relationships between forest structure, productivity and lateral carbon export rates, and independent estimates of forest inundation area in relation to tidal height are needed.

\section{Conclusions}

The SharkTREx 1 and 2 studies are the first to provide estimates of longitudinal DIC export, air-water $\mathrm{CO}_{2}$ fluxes, and mangrove-derived DIC inputs for the Shark and Harney rivers. The results show that air-water $\mathrm{CO}_{2}$ exchange and longitudinal DIC fluxes account for ca. $90 \%$ of the mangrove-derived dissolved carbon export out of the Shark and Harney rivers, with the remainder being exported as dissolved organic carbon. 
The mangrove contribution to the total longitudinal flux was 6.5 to $8.9 \%$ for DIC and 4 to $18 \%$ for DOC. A lower bound estimate of the dissolved carbon export (DIC and DOC) from the forest surrounding Shark River during the wet season was 18.9 to $24.5 \mathrm{mmol} \mathrm{m}^{-2} \mathrm{~d}^{-1}$ with $15.9 \mathrm{~km}^{2}$ of mangrove contributing area. This basin-scale estimate is somewhat lower by comparison than other independent estimates of lateral carbon export from this mangrove forest. However, mangrove forest carbon export rates on an aerial basis are expected to vary with the spatial and temporal scales over which they are calculated, and depend on factors such as tidal inundation frequency, distance from the riverbank and the coast, and forest and soil characteristics.

Future experiments should investigate the contribution of DIC from groundwater to the rivers, by making measurements of $\delta^{13} \mathrm{C}_{\mathrm{DIC}}$ of groundwater, $\mathrm{Sr}$ and $\mathrm{Ca}$ concentrations in the river to quantify $\mathrm{CaCO}_{3}$ dissolution and to separate carbonate alkalinity from TAlk, radon to quantify groundwater discharge, and ${ }^{14} \mathrm{C}_{\mathrm{DIC}}$ to separate input of DIC from remineralization of organic matter from dissolution of $\mathrm{CaCO}_{3}$. Experiments should also examine the seasonal variability in the carbon dynamics and export, by conducting processbased studies like SharkTREx during both wet and dry seasons. Also, time series measurement of current velocities, wind speeds, $p \mathrm{CO}_{2}$ and $\mathrm{pH}$ (to calculate DIC), DO, chromophoric dissolved organic matter (CDOM, as a proxy for DOC), and radon will also allow for the temporal variability of the sources and sinks of DIC in these rivers to be examined.

Data availability. The $p \mathrm{CO}_{2}$ data collected during SharkTREx 1 and 2 are available from the SOCAT database www.socat.info. The other data may be obtained by contacting the corresponding author.

Author contributions. David T. Ho, Sara Ferrón, and Victor C. Engel conceived and executed the experiment, interpreted the data, and prepared the manuscript with input from the other authors. William T. Anderson measured the samples for $\delta^{13} \mathrm{C}$ of dissolved organic carbon, Peter K. Swart measured the samples for $\delta^{13} \mathrm{C}$ of dissolved inorganic carbon, René M. Price measured the total alkalinity samples for SharkTREx 1, and Leticia Barbero measured the total alkalinity and dissolved inorganic carbon samples for SharkTREx 2.

Competing interests. The authors declare that they have no conflict of interest.

Acknowledgements. We thank J. Barr, T. Custer, L. Larsen, M. Reid, and M. Vázquez-Rodriguez for assistance in the field, A. Arik, N. Coffineau, and J. Harlay for assistance with data analysis, R. Wanninkhof and R. Zeebe for helpful discussions and comments, M. Sukop for the use of his laboratory, and P. Sullivan for analyzing the total alkalinity samples during SharkTREx 1. K. Kotun and Everglades National Park provided boats, fuel, and logistical support for the experiment. Shark River flow velocity data were obtained from USGS via the National Water Information System. Funding was provided by National Park Service through the Critical Ecosystem Studies Initiative (cooperative agreement H5284-08-0029) and by National Science Foundation through the Water Sustainability and Climate solicitation (EAR 1038855). René M. Price was supported by the Florida Coastal Everglades Long-Term Ecological Research program under National Science Foundation grant nos. DBI-0620409 and DEB-1237517. This is SERC contribution number 828. Any use of trade, product, or firm names is for descriptive purposes only and does not imply endorsement by the U.S. Government.

Edited by: K. Fennel

Reviewed by: two anonymous referees

\section{References}

Alongi, D. M.: Coastal Ecosystem Processes, CRC Marine Science Series, edited by: Kennish, M. J. and Lutz, P. L., CRC press, Boca Raton, 448 pp., 1998.

Alongi, D. M., Pfitzner, J., Trott, L. A., Tirendi, F., Dixon, P., and Klumpp, D. W.: Rapid sediment accumulation and microbial mineralization in forests of the mangrove Kandelia candel in the Jiulongjiang Estuary, China, Estuar. Coast. Shelf S., 63, 605-618, doi:10.1016/j.ecss.2005.01.004, 2005.

Anderson, W. T. and Fourqurean, J. W.: Intra- and interannual variability in seagrass carbon and nitrogen stable isotopes from south Florida, a preliminary study, Org. Geochem., 34, 185-194, doi:10.1016/S0146-6380(02)00161-4, 2003.

Barr, J. G., Engel, V., Smith, T. J., and Fuentes, J. D.: Hurricane disturbance and recovery of energy balance, $\mathrm{CO}_{2}$ fluxes and canopy structure in a mangrove forest of the Florida Everglades, Agr. Forest Meteorol., 153, 54-66, doi:10.1016/j.agrformet.2011.07.022, 2012.

Barr, J. G., Fuentes, J. D., DeLonge, M. S., O'Halloran, T. L., Barr, D., and Zieman, J. C.: Summertime influences of tidal energy advection on the surface energy balance in a mangrove forest, Biogeosciences, 10, 501-511, doi:10.5194/bg-10-501-2013, 2013.

Bergamaschi, B. A., Krabbenhoft, D. P., Aiken, G. R., Patino, E., Rumbold, D. G., and Orem, W. H.: Tidally Driven Export of Dissolved Organic Carbon, Total Mercury, and Methylmercury from a Mangrove-Dominated Estuary, Environ. Sci. Technol., 46, 1371-1378, doi:10.1021/es2029137, 2011.

Borges, A. V.: Do we have enough pieces of the jigsaw to integrate $\mathrm{CO}_{2}$ fluxes in the coastal ocean?, Estuaries, 28, 3-27, doi:10.1007/BF02732750, 2005.

Borges, A. V., Djenidi, S., Lacroix, G., Théate, J., Delille, B., and Frankignoulle, M.: Atmospheric $\mathrm{CO}_{2}$ flux from mangrove surrounding waters, Geophys. Res. Lett., 30, 1558, doi:10.1029/2003GL017143, 2003.

Bouillon, S., Frankignoulle, M., Dehairs, F., Velimirov, B., Eiler, A., Abril, G., Etcheber, H., and Borges, A. V.: Inorganic and organic carbon biogeochemistry in the Gautami Godovari estuary (Andhra Pradesh, India) during pre-monsoon: The local im- 
pacts of extensive mangrove forests, Global Biogeochem. Cy., 17, 1114, doi:10.1029/2002GB002026, 2003.

Bouillon, S., Dehairs, F., Schiettecatte, L.-S., and Borges, A. V.: Biogeochemistry of the Tana estuary and delta (northern Kenya), Limnol. Oceanogr., 52, 46-59, doi:10.4319/lo.2007.52.1.0046, 2007a.

Bouillon, S., Dehairs, F., Velimirov, B., Abril, G., and Borges, A. V.: Dynamics of organic and inorganic carbon across contiguous mangrove and seagrass systems (Gazy Bay, Kenya), J. Geophys. Res., 112, G02018, doi:10.1029/2006JG000325, 2007b.

Bouillon, S., Middelburg, J. J., Dehairs, F., Borges, A. V., Abril, G., Flindt, M. R., Ulomi, S., and Kristensen, E.: Importance of intertidal sediment processes and porewater exchange on the water column biogeochemistry in a pristine mangrove creek (Ras Dege, Tanzania), Biogeosciences, 4, 311-322, doi:10.5194/bg-4311-2007, 2007c.

Bouillon, S., Borges, A. V., Castañeda-Moya, E., Diele, K., Dittmar, T., Duke, N. C., Kristensen, E., Lee, S. Y., Marchand, C., Middelburg, J. J., Rivera-Monroy, V. H., Smith, T. J., and Twilley, R. R.: Mangrove production and carbon sinks: A revision of global budget estimates, Global Biogeochem. Cy., 22, GB2013, 10.1029/2007GB003052, 2008a.

Bouillon, S., Connolly, R. M., and Lee, S. Y.: Organic matter exchange and cycling in mangrove ecosystems: Recent insights from stable isotope studies, J. Sea Res., 59, 44-58, doi:10.1016/j.seares.2007.05.001, 2008b.

Boyer, J. N., Fourqurean, J. W., and Jones, R. D.: Spatial characterization of water quality in Florida Bay and Whitewater Bay by multivariate analyses: Zones of similar influence, Estuaries, 20, 743-758, doi:10.2307/1352248, 1997.

Breithaupt, J. L., Smoak, J. M., Smith, T. J., and Sanders, C. J.: Temporal variability of carbon and nutrient burial, sediment accretion, and mass accumulation over the past century in a carbonate platform mangrove forest of the Florida Everglades, J. Geophys. Res., 119, 2032-2048, doi:10.1002/2014JG002715, 2014.

Cai, W.-J. and Wang, Y.: The chemistry, fluxes, and sources of carbon dioxide in the estuarine waters of the Satilla and Altamaha Rivers, Georgia, Limnol. Oceanogr., 43, 657-668, 1998.

Call, M., Maher, D. T., Santos, I. R., Ruiz-Halpern, S., Mangion, P., Sanders, C. J., Erler, D. V., Oakes, J. M., Rosentreter, J., Murray, R., and Eyre, B. D.: Spatial and temporal variability of carbon dioxide and methane fluxes over semi-diurnal and spring-neapspring timescales in a mangrove creek, Geochim. Cosmochim. Ac., 150, 211-225, doi:10.1016/j.gca.2014.11.023, 2015.

Castañeda-Moya, E., Twilley, R. R., Rivera-Monroy, V. H., Marx, B. D., Coronado-Molina, C., and Ewe, S. M. L.: Patterns of Root Dynamics in Mangrove Forests Along Environmental Gradients in the Florida Coastal Everglades, USA, Ecosystems, 14, 11781195, doi:10.1007/s10021-011-9473-3, 2011.

Castañeda-Moya, E., Twilley, R. R., and Rivera-Monroy, V. H.: Allocation of biomass and net primary productivity of mangrove forests along environmental gradients in the Florida Coastal Everglades, USA, Forest Ecol. Manag., 307, 226-241, doi:10.1016/j.foreco.2013.07.011, 2013.

Cawley, K. M., Yamashita, Y., Maie, N., and Jaffé, R.: Using Optical Properties to Quantify Fringe Mangrove Inputs to the Dissolved Organic Matter (DOM) Pool in a Subtropical Estuary, Estuar. Coast., 37, 399-410, doi:10.1007/s12237-013-9681-5, 2013.
Chapin, F. S., Woodwell, G. M., Randerson, J. T., Rastetter, E. B., Lovett, G. M., Baldocchi, D. D., Clark, D. A., Harmon, M. E., Schimel, D. S., Valentini, R., Wirth, C., Aber, J. D., Cole, J. J., Goulden, M. L., Harden, J. W., Heimann, M., Howarth, R. W., Matson, P. A., McGuire, A. D., Melillo, J. M., Mooney, H. A., Neff, J. C., Houghton, R. A., Pace, M. L., Ryan, M. G., Running, S. W., Sala, O. E., Schlesinger, W. H., and Schulze, E.-D.: Reconciling Carbon-cycle Concepts, Terminology, and Methods, Ecosystems, 9, 1041-1050, doi:10.1007/s10021-005-01057, 2006.

DeNiro, M. J. and Epstein, S.: Influence of diet on the distribution of carbon isotopes in animals, Geochim. Cosmochim. Ac., 42, 495-506, doi:10.1016/0016-7037(78)90199-0, 1978.

Dettmann, E. H.: Effect of water residence time on annual export and denitrification of nitrogen in estuaries: A model analysis, Estuaries, 24, 481-490, doi:10.2307/1353250, 2001.

Dickson, A. G.: Standards for ocean measurements, Oceanography, 23, 34-47, doi:10.5670/oceanog.2010.22, 2010.

Dittmar, T. and Lara, R. J.: Do mangroves rather than rivers provide nutrients to coastal environments south of the Amazon River? Evidence from long-term flux measurements, Mar. Ecol.-Prog. Ser., 213, 67-77, 2001

Dittmar, T., Hertkorn, N., Kattner, G., and Lara, R. J.: Mangroves, a major source of dissolved organic carbon to the oceans, Global Biogeochem. Cy., 20, GB1012, doi:10.1029/2005GB002570, 2006.

Fischer, H. B., List, E. J., Imberger, J., Koh, R. C. Y., and Brooks, N. H.: Mixing in inland and coastal waters, Academic Press, New York, 483 pp., 1979.

Garcia, H. E. and Gordon, L. I.: Oxygen solubility in seawater: better fitting equations, Limnol. Oceanogr., 37, 1307-1312, doi:10.4319/lo.1992.37.6.1307, 1992.

He, D., Mead, R. N., Belicka, L., Pisani, O., and Jaffé, R.: Assessing source contributions to particulate organic matter in a subtropical estuary: A biomarker approach, Org. Geochem., 75, 129-139, doi:10.1016/j.orggeochem.2014.06.012, 2014.

Ho, D. T., Schlosser, P., and Caplow, T.: Determination of longitudinal dispersion coefficient and net advection in the tidal Hudson River with a large-scale, high resolution $\mathrm{SF}_{6}$ tracer release experiment, Environ. Sci. Technol., 36, 3234-3241, doi:10.1021/es015814+, 2002.

Ho, D. T., Ferrón, S., Engel, V. C., Larsen, L. G., and Barr, J. G.: Air-water gas exchange and $\mathrm{CO}_{2}$ flux in a mangrove-dominated estuary, Geophys. Res. Lett., 41, 108-113, doi:10.1002/2013GL058785, 2014.

Ho, D. T., Coffineau, N., Hickman, B., Chow, N., Koffman, T., and Schlosser, P.: Influence of current velocity and wind speed on airwater gas exchange in a mangrove estuary, Geophy. Res. Lett., 43, 3813-3821, doi:10.1002/2016GL068727, 2016.

Howard, P. J. A.: The Carbon-Organic Matter Factor in Various Soil Types, Oikos, 15, 229-236, doi:10.2307/3565121, 1965.

Jaffe, R., Mead, R., Hernandez, M. E., Peralba, M. C., and DiGuida, O. A.: Origin and transport of sedimentary organic matter in two subtropical estuaries: a comparative, biomarkerbased study, Org. Geochem., 32, 507-523, doi:10.1016/S01466380(00)00192-3, 2001.

Jähne, B., Munnich, K. O., Bosinger, R., Dutzi, A., Huber, W., and Libner, P.: On the parameters influencing 
air-water gas exchange, J. Geophys. Res., 92, 1937-1949, doi:10.1029/JC092iC02p01937, 1987.

Jennerjahn, T. C. and Ittekkot, V.: Relevance of mangroves for the production and deposition of organic matter along tropical continental margins, Naturwissenschaften, 89, 23-30, doi:10.1007/s00114-001-0283-x, 2002.

Keeling, R. F. and Manning, A. C.: Studies of Recent Changes in Atmospheric $\mathrm{O}_{2}$ Content, in: Treatise on Geochemistry, 2nd Edn., edited by: Holland, H. D. and Turekian, K. K., Elsevier, Oxford, 385-404, 2014.

Kieckbusch, D. K., Koch, M. S., Serafy, J. E., and Anderson, W. T.: Trophic linkages of primary producers and consumers in fringing mangroves of tropical lagoons, B. Mar. Sci., 74, 271-285, 2004.

Koné, Y. J.-M. and Borges, A. V.: Dissolved inorganic carbon dynamics in the waters surrounding forested mangroves of the $\mathrm{Ca}$ Mau Province (Vietnam), Estuar. Coast. Shelf S., 77, 409-421, doi:10.1016/J.Ecss.2007.10.001, 2008.

Kristensen, E., Bouillon, S., Dittmar, T., and Marchand, C.: Organic carbon dynamics in mangrove ecosystems: A review, Aquat. Bot., 89, 201-219, doi:10.1016/j.aquabot.2007.12.005, 2008.

Levesque, V. A.: Water Flow and Nutrient Flux from Five Estuarine Rivers along the Southwest Coast of the Everglades National Park, Florida, 1997-2001: U.S. Geological Survey Scientific Investigations Report 2004-5142, 24, 2004.

Maher, D. T., Santos, I. R., Golsby-Smith, L., Gleeson, J., and Eyre, B. D.: Groundwater-derived dissolved inorganic and organic carbon exports from a mangrove tidal creek: The missing mangrove carbon sink?, Limnol. Oceanogr., 58, 475-488, doi:10.4319/lo.2013.58.2.0475, 2013.

Mancera-Pineda, J. E., Twilley, R. R., and Rivera-Monroy, V. H.: Carbon $\left(\delta^{13} \mathrm{C}\right)$ and nitrogen $\left(\delta^{15} \mathrm{~N}\right)$ isotopic discrimination in mangroves in Florida Coastal Everglades as a function of environmental stress, Contrib. Mar. Sci., 38, 109-129, 2009.

Miyajima, T., Tsuboi, Y., Tanaka, Y., and Koike, I.: Export of inorganic carbon from two Southeast Asian mangrove forests to adjacent estuaries as estimated by the stable isotope composition of dissolved inorganic carbon, J. Geophys. Res., 114, G01024, doi:10.1029/2008JG000861, 2009.

Mook, W. G. and Tan, T. C.: Stable carbon isotopes in rivers and estuaries, in: Biogeochemistry of the major world rivers, SCOPE Report 42, edited by: Degens, E. T., Kempe, S., and Richey, J. E., John Wiley \& Sons, Chichester, 245-264, 1991.

Pierrot, D., Lewis, E., and Wallace, D. W. R.: MS Excel Program Developed for $\mathrm{CO}_{2}$ System Calculations, ORNL/CDIAC-105a, Carbon Dioxide Information Analysis Center, Oak Ridge National Laboratory, U.S. Department of Energy, Oak Ridge, Tennessee, doi:10.3334/CDIAC/otg.CO2SYS_XLS_CDIAC105a, 2006

Price, R. M., Swart, P. K., and Fourqurean, J. W.: Coastal groundwater discharge - an additional source of phosphorus for the oligotrophic wetlands of the Everglades, Hydrobiologia, 569, 23-36, doi:10.1007/s10750-006-0120-5, 2006.
Rivera-Monroy, V. H., Twilley, R. R., Davis III, S. E., Childers, D. L., Simard, M., Chambers, R., Jaffé, R., Boyer, J. N., Rudnick, D. T., Zhang, K., Castañeda-Moya, E., Ewe, S. M. L., Price, R. M., Coronado-Molina, C., Ross, M., Smith III, T. J., Michot, B., Meselhe, E., Nuttle, W., Troxler, T. G., and Noe, G. B.: The role of the Everglades mangrove ecotone region (EMER) in regulating nutrient cycling and wetland productivity in South Florida, Crit. Rev. Env. Sci. Tec., 41, 663-669, doi:10.1080/10643389.2010.530907, 2011.

Rutherford, J. C.: River mixing, John Wiley \& Sons, New York, 347 pp., 1994.

Saha, A., Moses, C., Price, R., Engel, V., Smith III, T., and Anderson, G.: A Hydrological Budget (2002-2008) for a Large Subtropical Wetland Ecosystem Indicates Marine Groundwater Discharge Accompanies Diminished Freshwater Flow, Estuar. Coast., 35, 459-474, doi:10.1007/s12237-011-9454-y, 2012.

Salomons, W. and Mook, W. G.: Isotope Geochemistry of Carbonates in the Weathering Zone, in: Handbook of Environmental Isotope Geocbemistry, Vol. 2, The Terrestrial Environment, B, edited by: Fritz, P. and Fontes, J. C., Elsevier, Amsterdam, 239269, 1986.

Severinghaus, J. P.: Studies of the terrestrial $\mathrm{O}_{2}$ and carbon cycle in sand dune gases and in Biosphere 2, PhD thesis, Columbia University, New York, 50 pp., 1995.

Troxler, T. G., Barr, J. G., Fuentes, J. D., Engel, V., Anderson, G., Sanchez, C., Lagomasino, D., Price, R., and Davis, S. E.: Component-specific dynamics of riverine mangrove $\mathrm{CO}_{2}$ efflux in the Florida coastal Everglades, Agr. Forest Meteorol., 213, 273-282, doi:10.1016/j.agrformet.2014.12.012, 2015.

Twilley, R. R., Chen, R. H., and Hargis, T.: Carbon sinks in mangroves and their implications to carbon budget of tropical coastal ecosystems, Water, Air and Soil Polluiton, 64, 265-288, doi:10.1007/BF00477106, 1992.

US Geological Survey: National Water Information System data available on the World Wide Web (USGS Water Data for the Nation), available at: http://waterdata.usgs.gov/nwis/, last access: 10 February 2016.

Wanninkhof, R.: Relationship between wind speed and gas exchange over the ocean revisited, Limnol. Oceanogr.-Meth., 12, 351-362, doi:10.4319/lom.2014.12.351, 2014.

Weiss, R. F.: Carbon dioxide in water and seawater: the solubility of a non-ideal gas, Mar. Chem., 2, 203-215, doi:10.1016/03044203(74)90015-2, 1974.

Ya, C., Anderson, W., and Jaffé, R.: Assessing dissolved organic matter dynamics and source strengths in a subtropical estuary: Application of stable carbon isotopes and optical properties, Cont. Shelf Res., 92, 98-107, doi:10.1016/j.csr.2014.10.005, 2015.

Zhang, J., Quay, P. D., and Wilbur, D. O.: Carbon isotope fractionation during gas-water exchange and dissolution of $\mathrm{CO}_{2}$, Geochim. Cosmochim. Ac., 59, 107-114, doi:10.1016/00167037(95)91550-D, 1995. 